\title{
赤血球站二諸臟器細胞成分ノ實驗的 \\ 貧血ノ恢復二及ボス影響
}

第二編 諸藏器細胞成分ノ非經口的投與實驗

東京帝國大學傳染病研究所附属病院（主任 宮川数授）

祭學士岡正

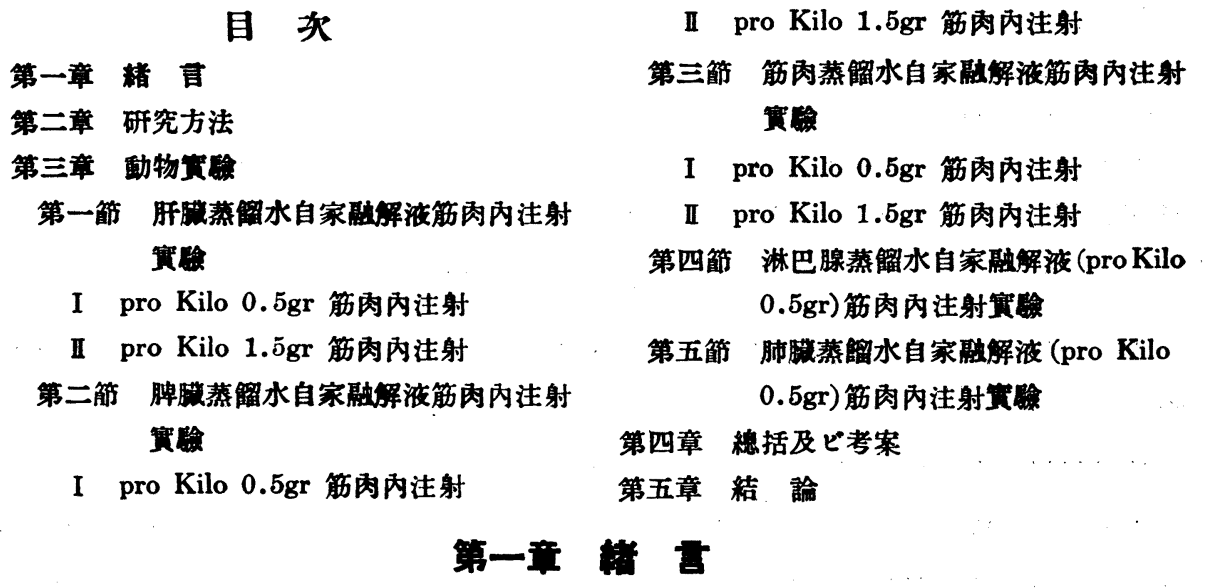

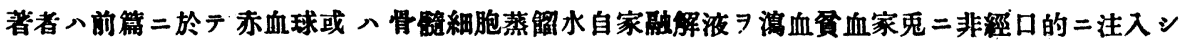

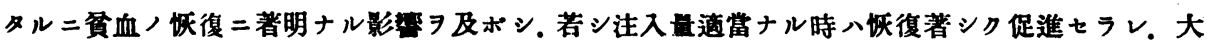

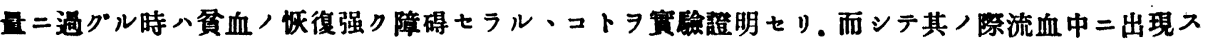

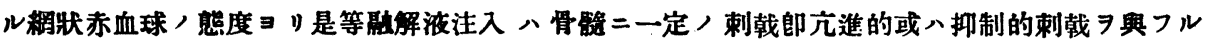

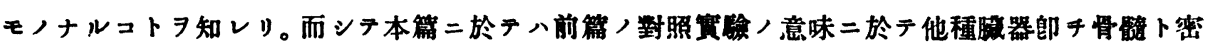

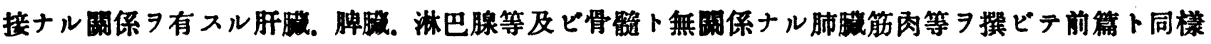
ナル方法ニテ處置シ。同槏ナル量的關係ニ於テ非經口的ニ注入シ彼我比較研究セントセり。

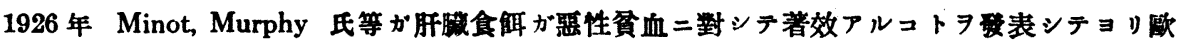
米各國學者八競七ナ其，道陚

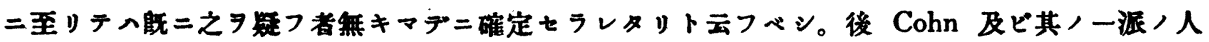

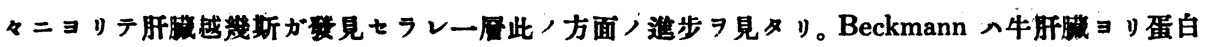

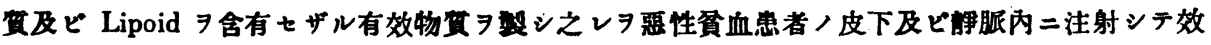

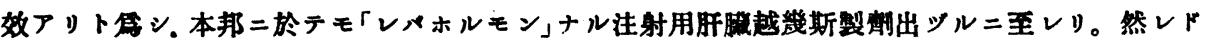

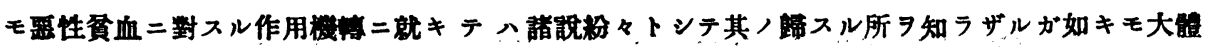

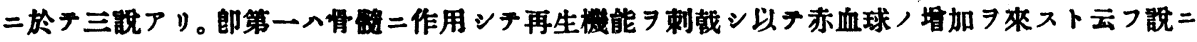

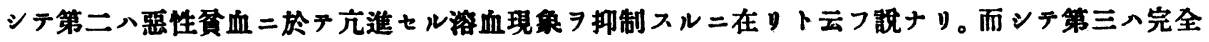


ナル赤血球 ヨ成生スルニ要スル或物宜 7 肝䐵食陬ニ依りテ供給スルニ在りト云フ考へナリ。

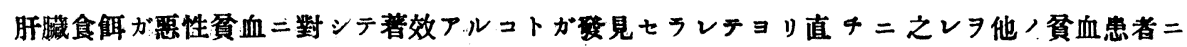

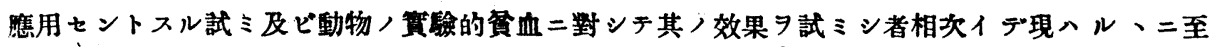

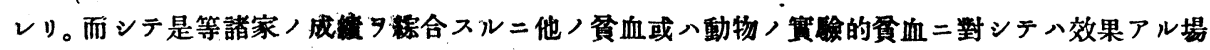
合卜無キ場合トアルモノニシテ. 效果アル場合卜雖モ惡性筫血二對スルガ如ク確賽且ツ著明ナル モノニ非ザルが如ン。

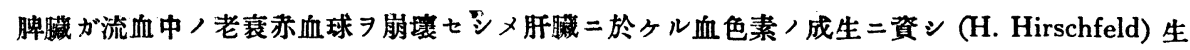
船鐵新陳代謝ノ重要ナル役割

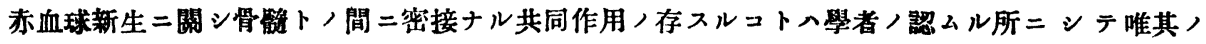

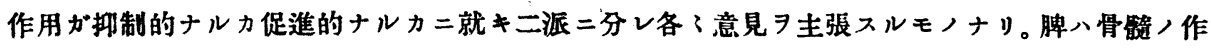
用 7 生理的二抑制スト、Ascher; Duboirs; Paton; Galland; Fowler; Vogel; Gruber 氏等，鿁 ニシテ之二反シ促進フルモノナリトハ Hirschfeld; Klemperer u. Hirschfeld; C. D. Leake \& E. W. Leake; Goldscheider u. Jacob; Simmon u. Spillmann;' Down \& Eddy; Danilewsky u. Selensky; Krumbhaar u. Musser; Gabbi 氏等ノ主張スル所ナリ。

脾臟成分タ注入シテ赤血球〉㙋加 Thalhiemer 等アリ.赤血球ノ滅少 $ヨ$ 來シタリトズルモノ= Down \& Eddy; 横森; 後藤氏等アリ。

\section{第二童 研究方法}

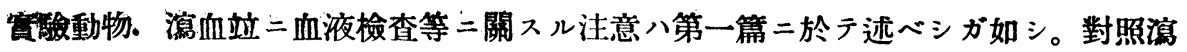
血貧血家兔ノ自然的恢復狀態二關シテモ前篇二於テ述べシ其䱾チ引用七リ。

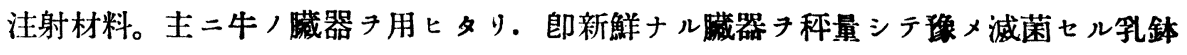
ニ入レテョク磨碎シ. そレニ隇菌蒸餾水 710 倍量二加へ水室內 $=12-24$ 時間放置七 ルモノキ用二臨々數枚ノ隇菌ガーゼ」ニテ滤過シ其ノ滤液き注射二供セリ。又時二各

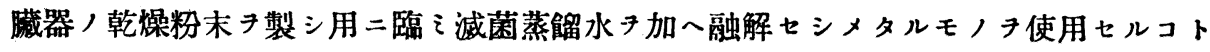
アリ。

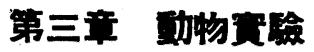

\begin{tabular}{|c|c|c|c|c|c|}
\hline $\mathbf{R}$ & 赤血球數 & $\mathrm{Hb}$ & 血色素量 (Sahli) & $\mathbf{w}$ & 白血球數 \\
\hline Ps & 偏エオジン嗜好細胞 & $\mathbf{L}$ & 漱巴球 & $\mathbf{M y}$ & 骨裙細胞 \\
\hline $\mathbf{m M y}$ & 後愲髄細胞 & St & 桿狀核細胞 & Sg & 分葉㤥細胞 \\
\hline $\mathbf{E}$ & エオジン咾好細胞 & B & 笽基啫好細胞 & Mon & 大單核細胞及移行型 \\
\hline $\mathbf{R z}$ & 刺䧕型 & $\mathrm{Nb}$ & 有核赤晌球 & Ret & 網狀赤血球數 \\
\hline I & III $\}$ 網狀赤血球，各型 & & 一海 血 & & \\
\hline
\end{tabular}

\section{第一節 肝臟細胞蒸鎦水自家融解液筋肉內注射賽驗}

I pro Kilo 0.5gr 注射 

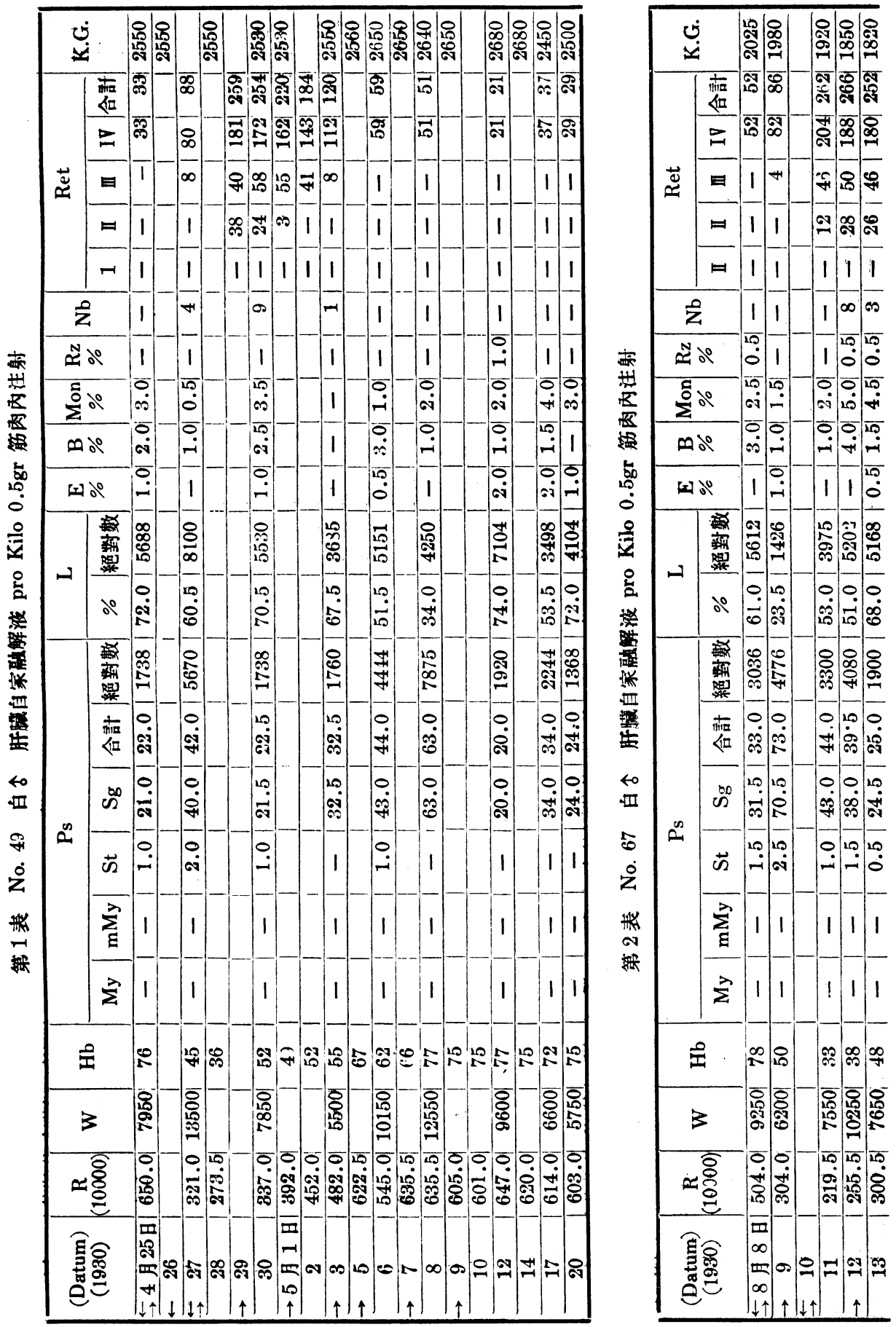


\begin{tabular}{|c|c|c|c|c|c|c|c|c|}
\hline & 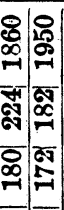 & & & & & & 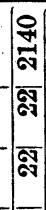 & $\mid$ \\
\hline & 72 & 11 & 11 & 1 & & 1 & 1 & 1 \\
\hline & 11 & 11 & 11 & 1 & & 1 & 1 & \\
\hline & 11 & 11 & 11 & 1 & 1 & 1 & 1 & \\
\hline & 1 & 11 & & 1 & 1 & & & \\
\hline & 1 & $\mid \begin{array}{ll}0 & 160 \\
-10\end{array}$ & & & $\mid \begin{array}{l}10 \\
0 \\
0\end{array}$ & 1 & 1 & \\
\hline & & $\mid \begin{array}{ll}10 \\
100\end{array}$ & & & $\mid \begin{array}{c}\bar{\pi} \\
\vec{\sigma}\end{array}$ & & o. & \\
\hline & & $\mid \begin{array}{ll}0 \\
0 \\
0\end{array}$ & & & $\mid \begin{array}{c}1 \\
0 \\
0\end{array}$ & 1 & $0^{\circ}$ & \\
\hline | & 1 & 111 & & 1 & 1 & - & 1 & 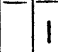 \\
\hline & & 足 & & & $\mid$ & & 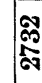 & \\
\hline & & & & & $\left|\begin{array}{l}0 \\
\dot{0} \\
\dot{0}\end{array}\right|$ & 0 & $\frac{10}{10}$ & \\
\hline & & 象 & & & 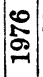 & $\infty$ & $\frac{20}{2}$ & 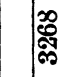 \\
\hline & & & & & $\left|\begin{array}{|c|}0 \\
0 \\
0 \\
\dot{m}\end{array}\right|$ & બ) & 20 & \\
\hline & & & & & 要 & 6 & & \\
\hline & & $\begin{array}{lll}10 & 10 \\
0 & 0\end{array}$ & & & $\begin{array}{l}10 \\
0\end{array}$ & & & \\
\hline & 1 & 11 & 1 & & 1 & 1 & 1 & \\
\hline & 1 & 11 & 1 & 1 & 1 & 1 & & \\
\hline & & & & & & & $\infty$ & \\
\hline & 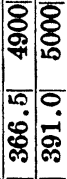 & 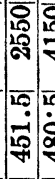 & م & 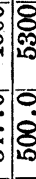 & & & 10.0 & 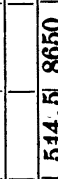 \\
\hline & & & & & & & & $\left|\begin{array}{l}0 \\
\uparrow\end{array}\right|$ \\
\hline
\end{tabular}

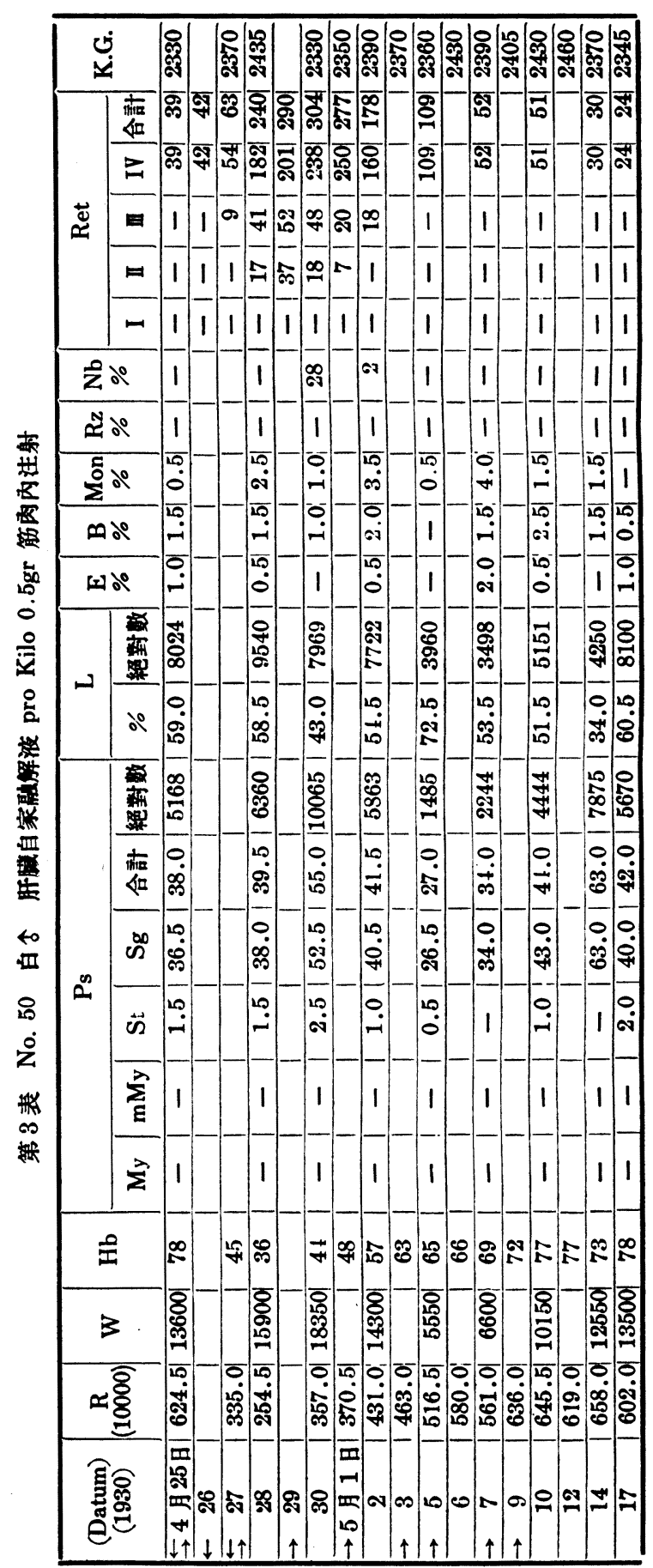




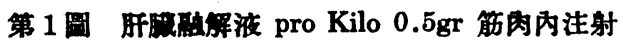

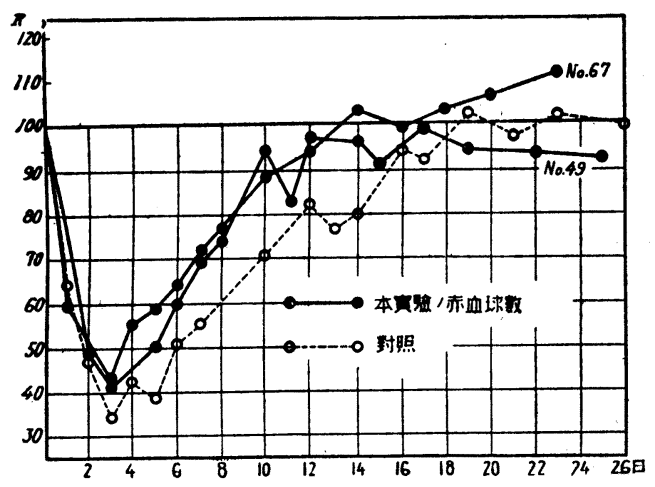

第 2 圆 肝腈融解液 pro Kilo $0.5 \mathrm{gr}$ 筋肉內注射

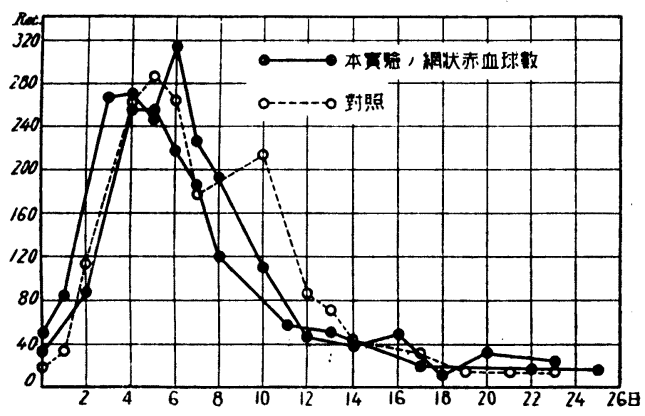

赤血球數ノ恢復狀照。

㴼血後 14-17 日ニシテ正常 二恢復 $ᄌ$. 郎對照㴼血動物二比 シ其,恢復期間多少促進七ラル ルガ如シ。然レドモ恢復期赤血 球過多症ハえレチ見ルコトナ シ。

血色素量，恢復狀態。 大能二於テ赤血球，恢復二一 致スルモNo. 49 二於テハ多少 速二. No. 50 及ビ 60 二於テ八 多少迤レテ恢復スルキ見ル。

赤血球 形態的變化。

對照瀉血動物二比シ著變ナ シ。

白血球數，變化。

何レモ第一次的增多症來り. No. 50 及ビ 67 二於テハ次文 減少症來ル。

白血球各型，變化。

榣エオシン嫩好細胞八白血球數，增減二一致シテ上下シ．淋巴球八第一次的增多症 二伴ヒ增加シテョリ溸次減少二傾キタル挠再ビ上昇シテ正常二恢復ス。其ノ他八著誉 ナシ。

粗狀赤血球 /消長。

3 -5 日月二夫々最高值 $259,304,316$ 二達ス。郎チ對照湭血動物卜略く一致シテ 消長 

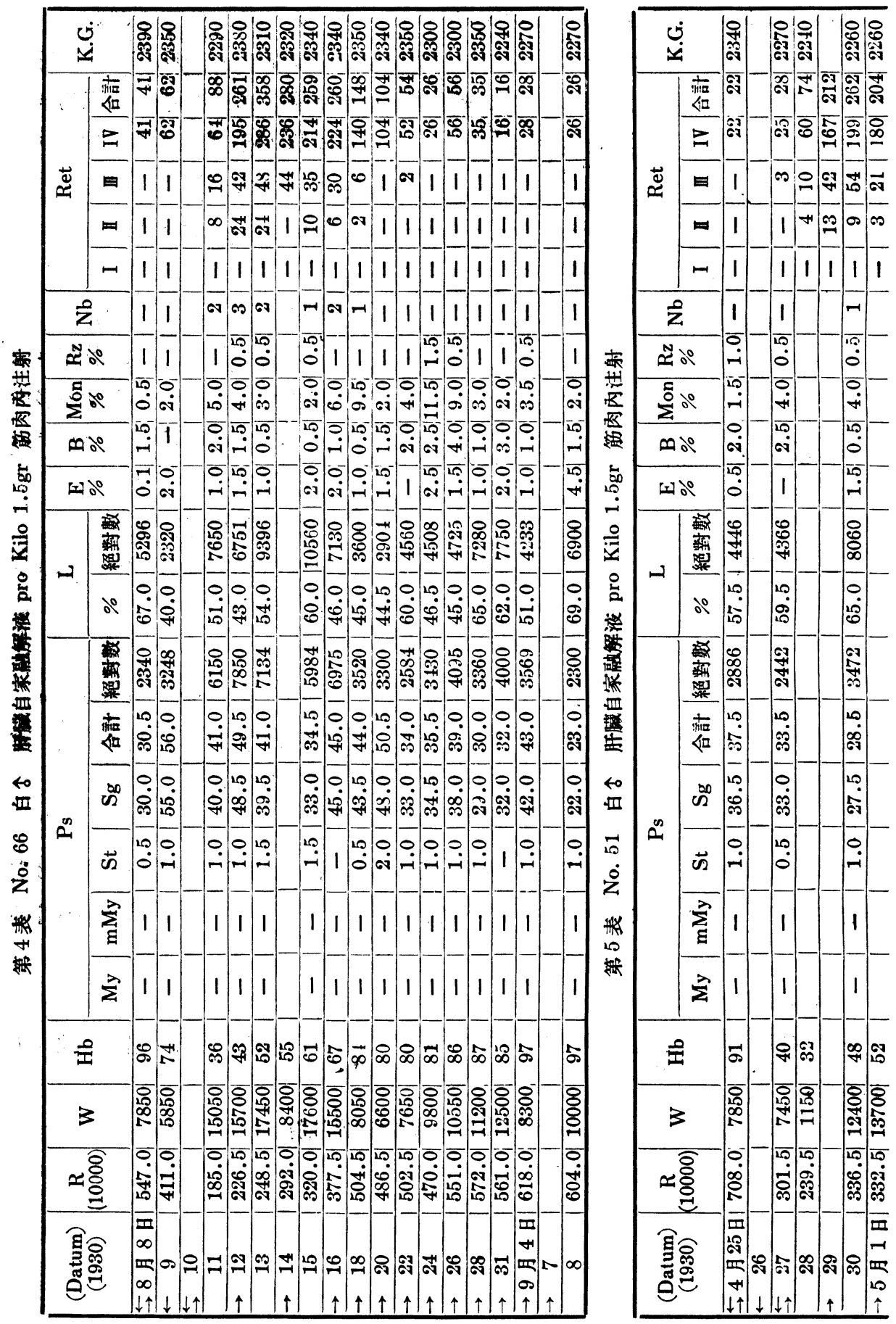


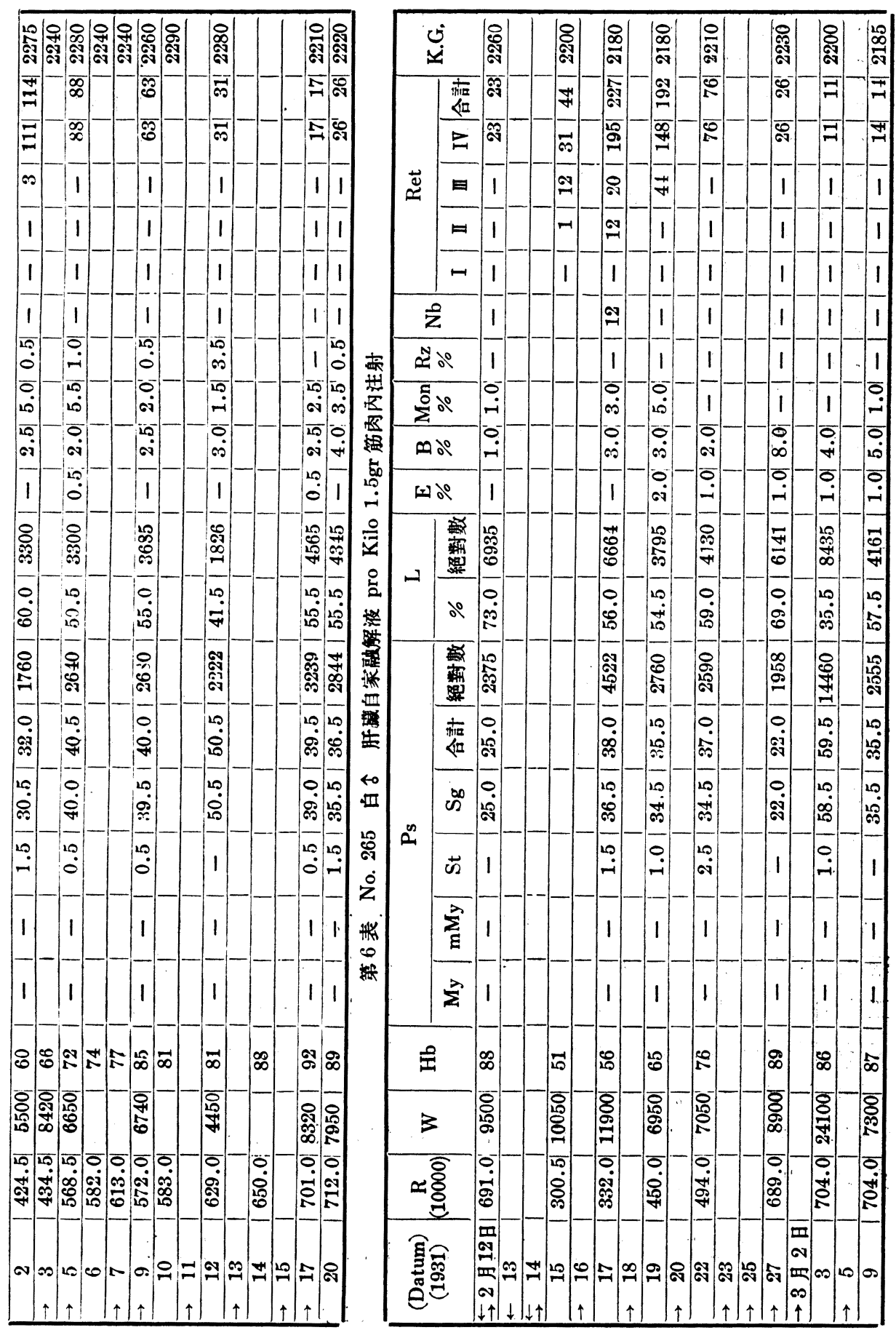




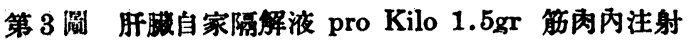

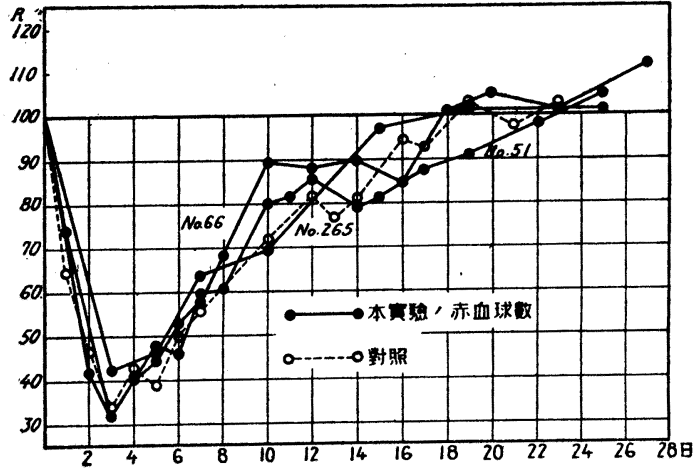

第 4 圆 肝䤑自家融解液 pro Kilo 1.5gr 筋肉內注射

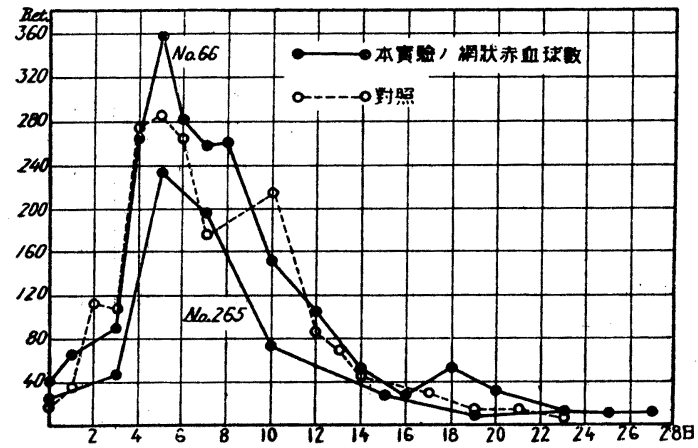

赤血球數, 恢復狀態。

No. 265 八 15 日. No. 66 八

18 日. No. 51 八 22 日ニシテ正 常二恢復 $、$ 。即其, 恢復曲線 $\exists$ ク對照䵘血動物ニ一致スルモ， ニシテ．赤血球或八骨锰細胞融 解液大量注入ノ場合ノ如ク貧血 八恢復抑制セラル、ガ如キコト ナシ。

血色素量ノ恢復狀態。

大體二於テ赤血球ノ恢復二件 ᄀ。

赤血球／型態的變化。

對照㴼血動物ト異ル所ナシ。

白血球數/督化。

第一次的增多症二次 1 デ不規 則ナル動播ナ示シッ、經過スル モノニシテ骨䯣細胞大量注射ノ 場合，如ク辢次減少症二詣クガ

如キコトナシ。

白血球各型, 變化。

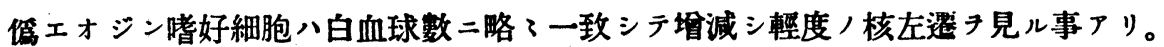
淋巴球八第一次的增多症二際シ輕度二增加シタル後減少シテ正常值以下二降り. 再ビ 正常二向ヒテ上昇スルガ如シ。エオジン郍好細胞. 刺戟型二八著變ナク.大單核細胞及 ビ移行型，第一次的增多症二一致シテ著名二增加ス。監基唓好細胞二八戀化き認メズ。

湅狀赤血球ノ消長。

何レモ 5 日目二夫々最高値 $227,358,262$ 二達シ. 漸次正常二復ス. 郎對照渞血貧 血動物ト異ル所ナシ。

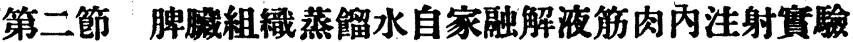

I pro Kilo $0.5 \mathrm{gr}$ 注射 


\begin{tabular}{|c|c|c|c|c|c|c|c|c|c|c|c|c|c|c|c|c|c|c|c|c|c|c|c|c|}
\hline نُ & 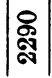 & 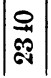 & ఫ్షి| & 党 & 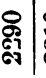 & ำ & & & 8 & 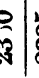 & חొ & ల్ల్ & & శ్షి & $\frac{9}{\pi}$ & สิ & |ট & $\mid$\begin{tabular}{l}
$\infty$ \\
\multirow{2}{*}{}
\end{tabular} & & نُ & 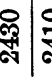 & | & & ్ㅕㄱ \\
\hline 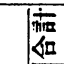 & 9 & $|\stackrel{\infty}{\sim}|$ & के & $\nexists$ & $\$$ & สิ & สิ & & : & $\theta$ & ș & హ్ & & 苇 & 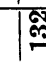 & 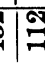 & 18 & के & & $\mid \begin{array}{l}h_{\text {Nin }} \\
\langle 0\end{array}$ & $\left.\frac{1}{2}\right|^{12}$ & का & & สี \\
\hline$\approx$ & 9 & $\stackrel{\infty}{\sim}$ & बू্ণ & $\infty$ & 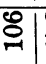 & $\stackrel{9}{9}$ & 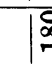 & & & 要 & 81 & 응 & & ్ㅏำ & 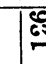 & 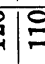 & $1^{10}$ & के & & $\approx$ & $\left.\infty\right|^{\frac{1}{\sigma}}$ & (6) & & 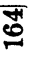 \\
\hline 过| & 1 & 1 & ๙ & है & ஃ̊ & สิ & 9 & s & & 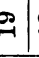 & 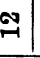 & \& & & $\infty$ & 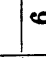 & $0 \circ$ & - & -1 & & 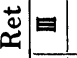 & 1 & 1 & & \& \\
\hline$a$ & 1 & 1 & 1 & 0 & 10 & $\stackrel{\infty}{\sim}$ & 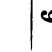 & 。 & & -1 & 1 & 1 & & 1 & 1 & 1 & 1 & 11 & & $\Rightarrow$ & 1 & 1 & & $\exists$ \\
\hline H & 1 & 1 & 1 & 1 & 1 & 1 & 1 & 1 & & 1 & 1 & 1 & & 1 & 1 & 1 & 1 & 11 & & - & 1 & I & & 1 \\
\hline$\hat{z}$ & 1 & 1 & & $\infty$ & $\infty 1$ & $\stackrel{\mathcal{I}}{\simeq}$ & $c$ & & & $\mathbf{v}$ & $\$$ & है & & $*$ & $\gamma$ & +10 & $\checkmark$ & \begin{tabular}{r|r} 
& ro
\end{tabular} & & $\hat{z}$ & 1 & 1 & -1 & $\stackrel{\infty}{\sim}$ \\
\hline है do & 11 & $\mid \begin{array}{c}10 \\
0\end{array}$ & & 11 & 量: & $\stackrel{0}{i}$ & 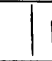 & 1 & & ? & 11 & 1 & & 1 & & $\left.\begin{array}{l}P \\
\dot{j}\end{array}\right|^{125}$ & \begin{tabular}{l|l} 
& 1
\end{tabular} & $1 \stackrel{1}{0}^{10}$ & & జ̃ do & 年: & 1 & & 1 \\
\hline है & $\mid \begin{array}{l}20 \\
0\end{array}$ & 190 & & \begin{tabular}{l|l} 
& \\
$i$ &
\end{tabular} & $\begin{array}{l}0 \\
+1\end{array}$ & 움 & & & & के & $\begin{array}{l}0 \\
0 \\
0\end{array}$ & 웅 & & $\stackrel{10}{-10}$ & & $\dot{5}: 5$ & 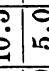 & \begin{tabular}{|l|l} 
\\
$\vdots$
\end{tabular} & & $\sum_{\Sigma}^{0} \circ$ & $\begin{array}{l}\stackrel{0}{0} \\
\dot{i}\end{array}$ & $\begin{array}{l}0 \\
+i\end{array}$ & & 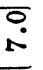 \\
\hline do do & $\left|\begin{array}{l}10 \\
0\end{array}\right|$ & 1 & & 1 & $\div$ & 1 & 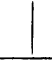 & I & & 1 & 11 & - & & मी & 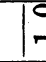 & \begin{tabular}{l|l} 
\\
-1 & 1
\end{tabular} & $11 \%$ & \begin{tabular}{|l|l} 
\\
\end{tabular} & 兌 & $\infty$ 20 & $\begin{array}{l}0 \\
-i \\
-1\end{array}$ & $\stackrel{0}{i}$ & & 1 \\
\hline cy do & $\left|\begin{array}{l}20 \\
0\end{array}\right|$ & 11 & & 11 & \begin{tabular}{|c|}
0 \\
0 \\
0
\end{tabular} & 1 & & I & & 1 & 11 & 1 & & 1 & & 1 & 10 & \begin{tabular}{l|l} 
\\
$-i$ & 1
\end{tabular} & 揾 & $\Leftrightarrow 2$ do & 官 & 1 & 1 & 1 \\
\hline 杪 & 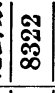 & 丞 & & 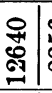 & $\begin{array}{l}\infty \\
\infty \\
\infty \\
\infty \\
\end{array}$ & $\vec{i}$ & & & & | & 웜 & ஜ & & ఫ్తి & & & 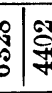 & 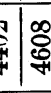 & $\begin{array}{c}10 \\
0 \\
0 \\
0 \\
0\end{array}$ & , & $\begin{array}{l}\stackrel{0}{0} \\
\stackrel{1}{\circ}\end{array}$ & 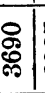 & & 원 \\
\hline 20 & $\left|\begin{array}{l}0 \\
\dot{P}\end{array}\right|$ & $\left|\begin{array}{l}20 \\
0 \\
0\end{array}\right|$ & & \begin{tabular}{|l|l|}
0 \\
$\dot{8}$ \\
$\infty$
\end{tabular} & \begin{tabular}{l|}
0 \\
$\dot{1}$ \\
$\stackrel{1}{1}$
\end{tabular} & فํ. & & & & & $\begin{array}{l}0 \\
+ \\
\infty\end{array}$ & 웅 & & & & & \begin{tabular}{l|l}
0 \\
$\dot{0}$
\end{tabular} & $\begin{array}{l}0 \\
\vdots \\
\vdots\end{array}$ & 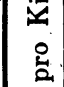 & $\therefore$ & \begin{tabular}{l|c}
0 \\
$\dot{1}$ \\
$\hat{10}$
\end{tabular} & $\begin{array}{l}0 \\
\dot{0} \\
0\end{array}$ & : & 迥 \\
\hline 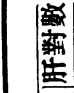 & 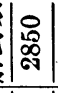 & ஓి & & 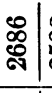 & $\begin{array}{l}\infty \\
0 \\
0 \\
\text { co }\end{array}$ & |⿱亠凶禸ٌ & & 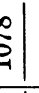 & & స్లై & ঞ্জ & \%ั & & ఫ్టి & $\oiint_{\sigma}$ & & & \begin{tabular}{l|l}
0 \\
0
\end{tabular} & 灌 & $\mid$ & 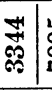 & $\begin{array}{l}2 \\
\stackrel{2}{\circ} \\
\stackrel{2}{\circ}\end{array}$ & & 㝵 \\
\hline 寉侣 & 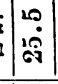 & | & & $\mid$ & $\frac{0}{6 .}$ & $\dot{\vec{d}}$ & & & & & $\begin{array}{l}0 \\
\stackrel{i}{a} \\
-\end{array}$ & $\begin{array}{l}0 \\
\dot{\leftrightarrow} \\
\stackrel{\leftrightarrow}{*}\end{array}$ & & & & & \begin{tabular}{l|l}
0 \\
$\dot{0}$
\end{tabular} & 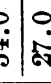 & 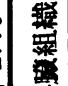 & 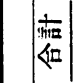 & 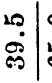 & \begin{tabular}{c|}
0 \\
1 \\
0
\end{tabular} & |ै। & 羊 \\
\hline$\pi^{\infty}$ & $\left|\begin{array}{l}20 \\
\dot{\vec{A}}\end{array}\right|$ & $\mid \stackrel{\text { | }}{\dot{\text { N}}}$ & & $\mid$ & | & 10 & & & & 吕 & $\begin{array}{l}0 \\
0\end{array}$ & تُ & & | & & & 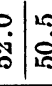 & ब & $\begin{array}{l}\text { 塩 } \\
\text { N }\end{array}$ & $\left.\sum_{\infty}^{\infty}\right|_{\infty} ^{\infty}$ & \begin{tabular}{l|l}
$\infty$ & 1 \\
$\infty$ & \\
$\infty$ &
\end{tabular} & $\begin{array}{l}10 \\
\text { هi } \\
0\end{array}$ & & iे \\
\hline$\vec{n}$ & $\stackrel{0}{-i}$ & $\stackrel{0}{-}$ & & 1 & 告 & هُ & & 1 & & | & $\begin{array}{c}0 \\
\dot{\infty}\end{array}$ & "9. & & م. & & 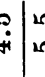 & \begin{tabular}{l|l}
0 \\
$:$
\end{tabular} & 1 & z & $\vec{n}$ & $\stackrel{0}{0}$ & a & | & هi \\
\hline$\sum_{\Sigma}^{2}$ & 1 & 1 & & 1 & 1 & 1 & & 1 & & 1 & 1 & is & & 1 & 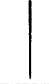 & 1 & P. & 1 & $\mid \begin{array}{l}\infty \\
\text { 强 }\end{array}$ & $\sum_{\boldsymbol{I}}^{\vec{Z}}$ & 1 & 1 & I & 1 \\
\hline$\sum_{\Sigma}^{2}$ & 1 & 1 & & 1 & 1 & 1 & & I & & 1 & 1 & 1 & & 1 & 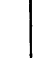 & 1 & 1 & 111 & & $\sum$ & 1 & 1 & 1 & \\
\hline 王 & $\infty$ & 10 & ने & $\ddot{m}$ & 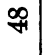 & î & & ใด & & 20 & 18 & 年 & & i⿱⺈ & 8 & है & 6 & 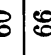 & & 全 & $\infty$ & 8 & F & $1+\frac{9}{2}$ \\
\hline 3 & 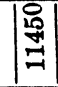 & $\left|\begin{array}{|l}\text { | } \\
\text { 量 } \\
0\end{array}\right|$ & $\mid$ & 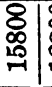 & 总 & 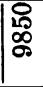 & & 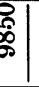 & & $\begin{array}{l}8 \\
0 \\
0 \\
\end{array}$ & 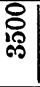 & 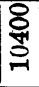 & & . & 5 & 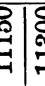 & $\begin{array}{l}3 \\
\end{array}$ & อ. & & 3 & $\begin{array}{l}8 \\
\infty \\
\infty \\
\infty\end{array}$ & 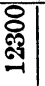 & 蛋 & \\
\hline $x$ & 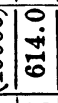 & $\left|\begin{array}{l}0 \\
\vdots \\
5 \\
+1\end{array}\right|$ & $\left|\begin{array}{c}0 \\
\dot{a} \\
\dot{a}\end{array}\right|$ & 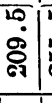 & | & 官 & & & & 定| & $\begin{array}{l}0 \\
0 \\
0 \\
0 \\
\\
\end{array}$ & 占 & & $\begin{array}{l}10 \\
100 \\
80 \\
0 \\
0\end{array}$ & $\vdots$ & $\begin{array}{l}0 \\
\dot{0} \\
0 \\
0\end{array}$ & \begin{tabular}{l|l}
5 \\
4 \\
4
\end{tabular} & 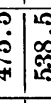 & & $x$ ठ & $\left|\begin{array}{l}0 \\
9 \\
10\end{array}\right|$ & | & & เั \\
\hline 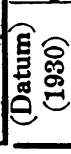 & 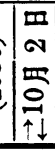 & & $\left|\begin{array}{c}+ \\
\uparrow \downarrow\end{array}\right|$ & & 0 & 1 & & o. & 의 & $\Rightarrow$ & 2 & 19 & & 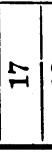 & & . & 6 & $\frac{8}{7} \mid \frac{5}{2}$ & & 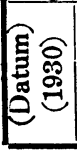 & $\left|\begin{array}{c}\mathbf{m} \\
\mathbf{N} \\
\mathbf{m} \\
\mathbf{9} \\
\mathbf{1}\end{array}\right|$ & $\infty$ & & \\
\hline
\end{tabular}




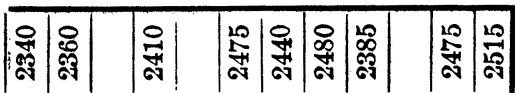

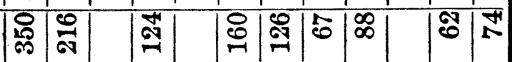

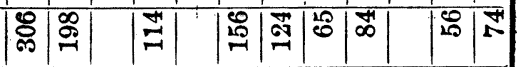

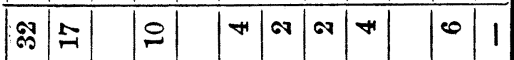

\begin{tabular}{|l|l|l|l|l|l|l|l|l|}
\hline$=$ & -1 & & 1 & & 1 & 1 & 1 & 1 \\
\hline
\end{tabular}

\begin{tabular}{|l|l|l|l|l|l|l|l|l|l|l|l|}
\hline-1 & 1 & 1 & 1 & 1 & 1 & 1 & & 1 & 1 \\
\hline
\end{tabular}

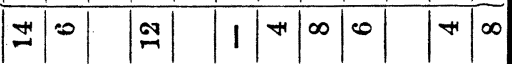

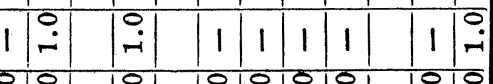

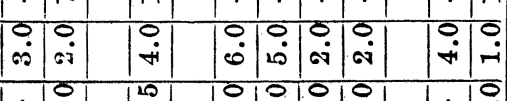

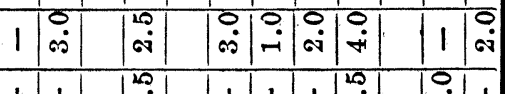

\begin{tabular}{|l|l|l|l|l|l|l|l|l|l|l|}
\hline 1 & 1 & $\mid \begin{array}{l}m \\
10\end{array}$ & 0 & 1 & 1 & 1 & 0 & 0 & 0 & 1 \\
\hline
\end{tabular}

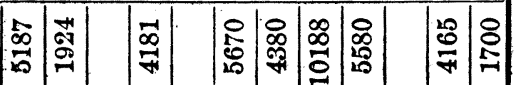

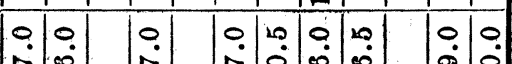

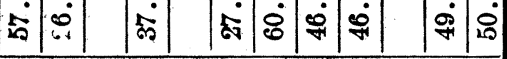

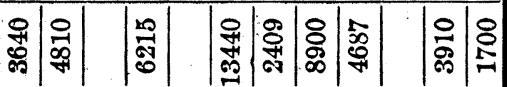

||ㅣㄹ.

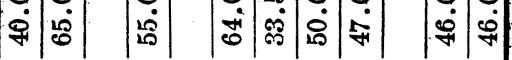

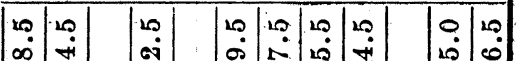

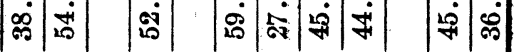

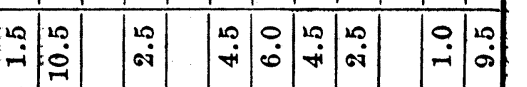

\begin{tabular}{|l|l|l|l|l|l|l|l|l|l|l|l|}
\hline 1 & 1 & & 1 & & 1 & 1 & 1 & 1 & & 1 & 1 \\
\hline
\end{tabular}

\begin{tabular}{|l|l|l|l|l|l|l|l|l|l|l|l|}
\hline 1 & 1 & & 1 & & 1 & 1 & 1 & 1 & & 1 & 1 \\
\hline
\end{tabular}

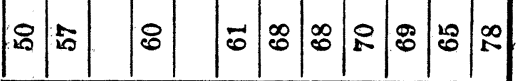

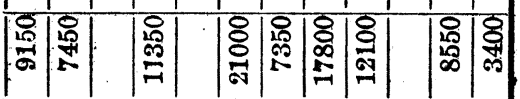

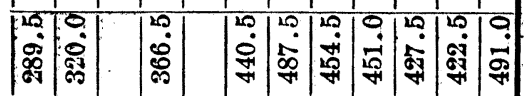

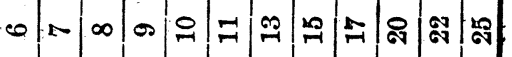

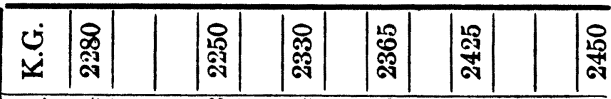

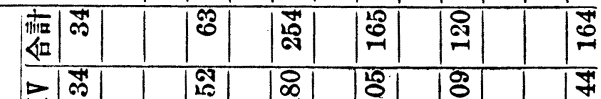

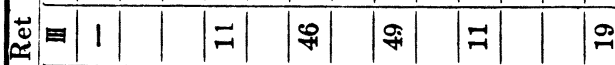

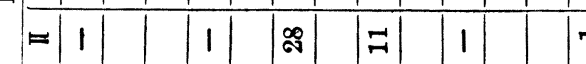

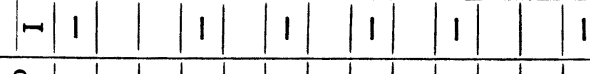

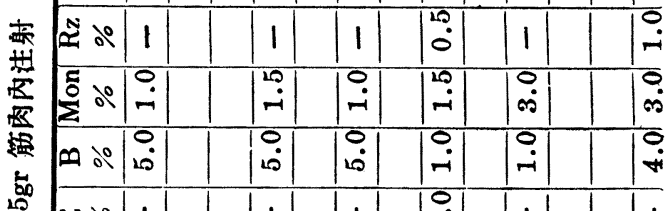

되

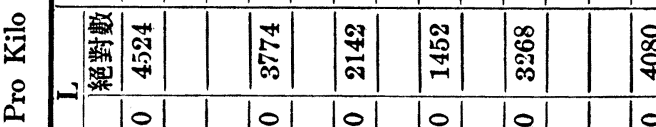

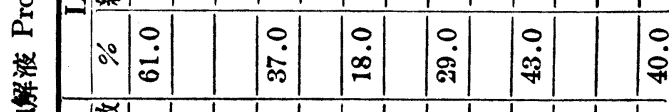

整

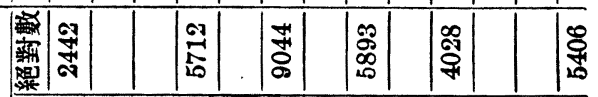

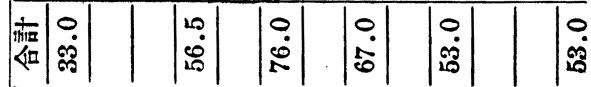

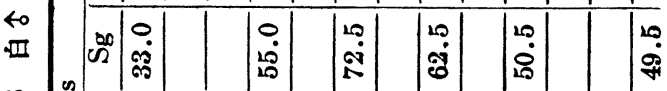

ż

Z

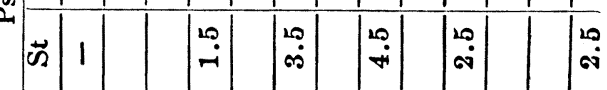

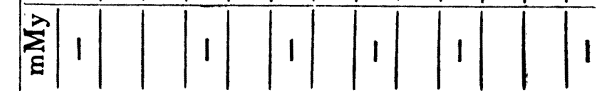

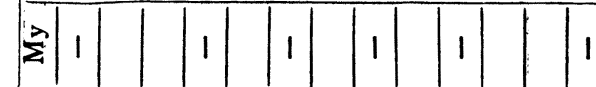

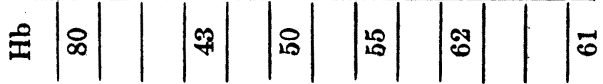

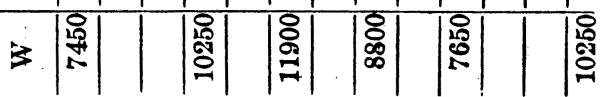

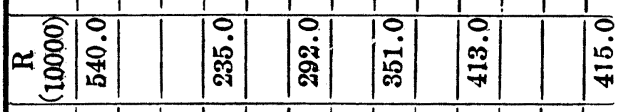

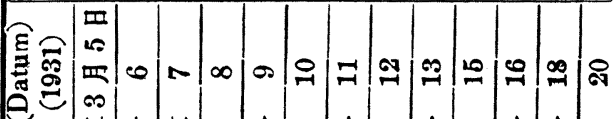




\begin{tabular}{|c|c|c|c|c|c|c|c|c|c|}
\hline | & & 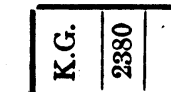 & | & & $\mid$ & | & $\mid$ & 愛 & \\
\hline$\left|\frac{|\pi|}{|\infty \phi|}\right|$ & |क्ष & 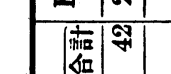 & $|9|$ & 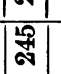 & | & $\mid$ & $|7|$ & F & \\
\hline$|2|$ & क्ष & $\approx|7|$ & $|\overrightarrow{\mid}|$ & 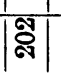 & $|\%|$ & $\left|\frac{2}{\mid}\right|$ & 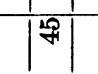 & $\$$ & \\
\hline $1+1$ & i. & 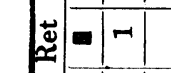 & 9 & $\mid$ & $|\%|$ & 101 & 11 & & \\
\hline$|1|$ & & $=11$ & 1 & $|\infty|$ & 11 & 11 & 11 & 1 & \\
\hline 11 & & $|-| 1 \mid$ & $|1|$ & $|1|$ & $|1|$ & 11 & $|1|$ & 1 & \\
\hline$|1|$ & & \begin{tabular}{|l|l|}
$\mathbf{z}$ & 1 \\
\end{tabular} & 11 & |क| & $|1|$ & 11 & 11 & 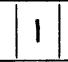 & \\
\hline$|1|$ & & $=211$ & $|\stackrel{i}{i}|$ & |1 & 11 & $|\stackrel{i}{i}|$ & | 1 & $\mid$ & \\
\hline$|0| \dot{i} \mid$ & 同 & 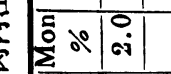 & $|\vec{\circ}|$ & $|i|$ & 1 & $|1|$ & $\mid \stackrel{\oplus}{|i|}$ & $|\stackrel{i}{|i|}|$ & \\
\hline$|\vec{i}|$ & 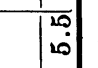 & 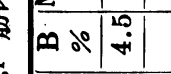 & $|0|$ & $|\vec{i}|$ & $|\vec{i}|$ & $|1|$ & 1 & 9 & \\
\hline$|\stackrel{i}{\mid}|$ & 10 & 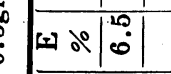 & $|\stackrel{+}{*}|$ & $|i|$ & $\mid \stackrel{i}{|i|}$ & 11 & $|0|$ & $|\stackrel{\oplus}{\mid}|$ & \\
\hline$|\overrightarrow{\mathrm{w}}|$ & 圆 & 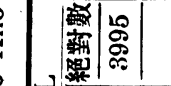 & |: & 澧] & $\mid$ & $\mid$ & 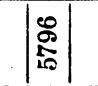 & $\mid$ & \\
\hline$\left|\begin{array}{l}0 \\
0\end{array}\right|$ & (0) & $\therefore\left|\begin{array}{l}0 \\
\dot{*}\end{array}\right|$ & $\left|\begin{array}{l}0 \\
\dot{q}\end{array}\right|$ & $\mid$ & $\mid \begin{array}{l}\mid \infty \\
\infty \\
\infty\end{array}$ & $\left|\begin{array}{|c|}\mid \infty \\
\$ \\
\$\end{array}\right|$ & $\left|\begin{array}{l}\mid \\
\vdots \\
\$\end{array}\right|$ & $\mid \begin{array}{l}\left|\begin{array}{l}\mid \\
\dot{\phi}\end{array}\right| \\
\mid\end{array}$ & \\
\hline $\mid \begin{array}{l}\mid \text { 总 } \\
\end{array}$ & 圈 & 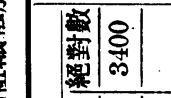 & $\mid$ & 染 & $\left|\begin{array}{l}\mid 0 \\
0 \\
1\end{array}\right|$ & | & 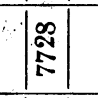 & | & \\
\hline$\left|\begin{array}{l}p \\
i \\
i\end{array}\right|$ & (a) & 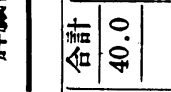 & $|\stackrel{\dot{m}}{\mid}|$ & $\mid$ & $\mid$\begin{tabular}{|c|}
$\left|\begin{array}{l}5 \\
0 \\
8\end{array}\right|$ \\
\end{tabular} & 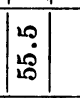 & $\left|\begin{array}{l}0 \\
\dot{b} \\
1\end{array}\right|$ & $\left|\begin{array}{l}\mid \vec{i} \\
\dot{i}\end{array}\right|$ & \\
\hline$\left|\begin{array}{l}0 \\
0 \\
0\end{array}\right|$ & 间递 & $\left|\begin{array}{l}\infty \\
\infty\end{array}\right| \begin{array}{l}0 \\
\dot{\infty}\end{array} \mid$ & $\left|\begin{array}{c}0 \\
0 \\
\cdots\end{array}\right|$ & $\left|\begin{array}{l}0 \\
\dot{5}\end{array}\right|$ & 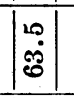 & $\mid$ & $\left|\begin{array}{l}0 \\
0 \\
0\end{array}\right|$ & 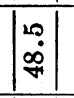 & \\
\hline$|\stackrel{+}{\mid}|$ & 19 & 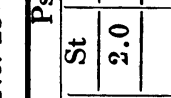 & $\mid$ & 1 & 11 & $|\vec{\circ}|$ & $\mid+\infty$ & $\mid$ & \\
\hline 11 & & 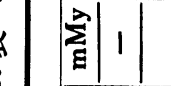 & 1 & 11 & 1 & 11 & 11 & 11 & \\
\hline 11 & & $\frac{2}{2} \mid 1$ & 11 & 1 & 1 & 1 & 1 & 1 & \\
\hline$|:|$ & $|x|$ & $\left|\frac{2}{ \pm \mid}\right|$ & $|\%|$ & $\%$ & $|:|$ & $|\infty|$ & $|m|$ & $|\vec{a}|$ & \\
\hline $\mid$ & 㣢 & \begin{tabular}{|l|l|l|l|l|} 
\\
\end{tabular} & $\mid$ & | & | & | & $\mid$ & $\mid$ & \\
\hline$\left|\begin{array}{l}\dot{p} \\
\hat{f}\end{array}\right|$ & | & 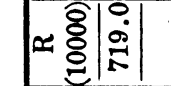 & $\mid$ & 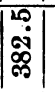 & $\mid$ & $\mid$ & $\mid$ & $\mid$ & \\
\hline & & & & & & & & & \\
\hline
\end{tabular}


第 5 圖 脾戥組樴融解波 pro Kilo $0.5 \mathrm{gr}$ 注射

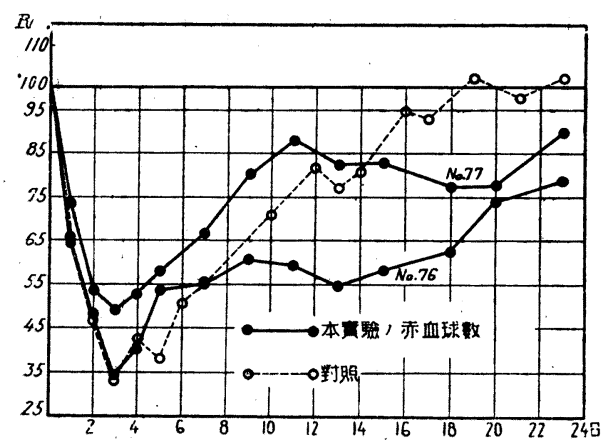

第 6 圖 脾腰組糡融解液 pro Kilo 0.5gr 注射

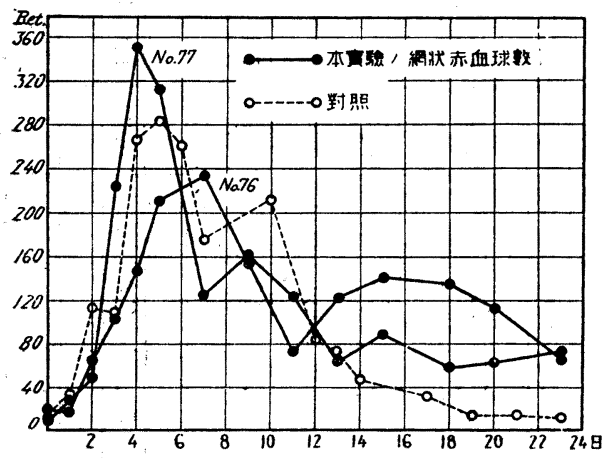

赤血球數ノ恢復狀態。

何レモ 1 週間前後迄ハヨク恢復二 向フモ融解液注入 $\ni$ 持續スル時八恢 復抑制セラレ或ハ中止シ. No.77， 如キ八更二赤血球減少二傾ク。郎融 解液注射 ノ障碍ヨ及ボスコト明カナリ。而シ テ注射テ中止スル時八直 $チ 二$ 恢復二 向フモノナリ。

血色素量，恢復狀態。

略 ?正血球數二一致シテ增減ス。 赤血球ノ形態的變化。

No. 76 及 77 二於于八初期恢復期 二際 シ極メテ多數/有核赤血球出現 シ. No. 76 二於テ八 10 日目頃再ビ 著明二增加セり。而シテ各動物共二 全經過き通ジテ永ク有核赤血球皃 ルモノニシテ對照䵘血動物ト大イ二 異ル所ナリ。Polychromasie, Ani-

socztose, Poikilozytose等八初期二於テ著名二增加シタル後渐次減少スルモ全ク正常 二復スル事ナク．No. 77 八如キ八再ビ增强スルテ見ル。

白血球數 /變化。

全經過キ通ジテ增多症或ハ隇少症不規則ニ來り一定，變化キ見出シ難シ。 白血球各型ノ變化。

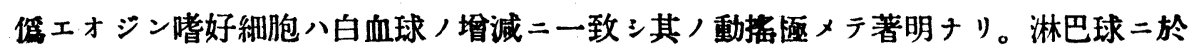
ナモ强キ動播キ示シ一定ノ罗解ヨ把握シ難キモ一般二正常值以下二減少スルコト稀ナ y．之レ他/融解液注入ノ場合卜多少異ナレル所見ナリ。監基喈好緗胞及ビ大單核細 胞ハ全經過き通ジテ多少增加シ・エオジン搘好細胞近二刺戟型ハ變化テ示サズ。

棢狀赤血球，消長。

初期二增加シテョリ漸次減少ニ向フモ正常二復スルコトナク增加ノ狀態き持績ス。 其（間多少ノ動播き見ルコトアリ。No.77, 如ク再ビ贫血二向フ如キモノニアッテ 
八其ノ時期二一致シテ網狀赤血球再ビ增加スルコトアリ。而シテ注射き持績スル時八 全經過き通ジテ幼弱型郎第II 型及ビ第吕型等ノ出現キ見ルモノナリ。之ニヨりテ骨髓

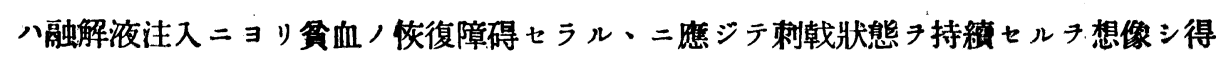
ルモノナリ。

\section{II pro Kilo $1.5 \mathrm{gr}$ 注射}

第 7 圖 脾搭組織融解液 pro Kilo $1.5 \mathrm{gr}$ 注射

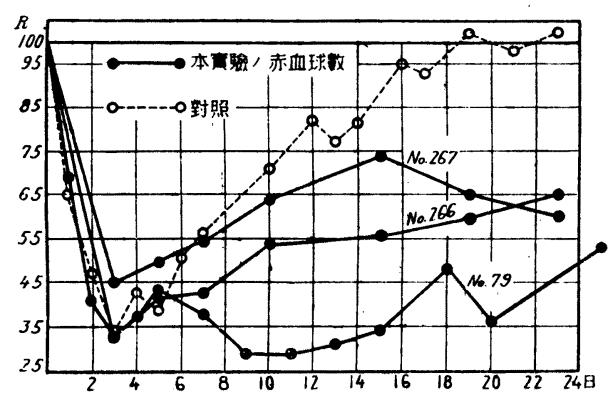

第 8 圖 脾脿組糡融解液 pro.Kilo $1.5 \mathrm{gr}$ 注射

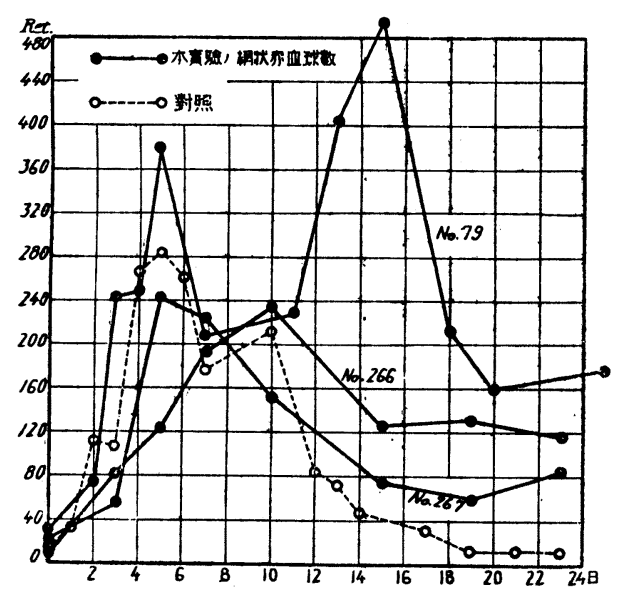

赤血球數 , 恢復狀態。

No. 79 ニアリテハ 5 日目迄小恢 復二向七. No. 266,267 二於テ八最 初ヨリ恢復極メテ逮々トシテ進行シ No. 267 二在りテハ15 日目頃 $ヨ$ ! 再ビ赤血球減少二傾ケリ。之き要ス ル二䳆血後，資血／恢復或八抑制七 ラレ. 或八中止シ. 或八更二赤血曃 減少二向フ等極メテ著明二其八恢復 障碍七ラル、モノナリ。

血色素量 /恢復㫿態。

略了赤血球ノ增減二一致シテ經過 ス.

赤血球 / 形態的變化。

Polychrom:sie, Anisozytose, Poikilozytose 等初期二於テ著明二 增加シテョリ一時減少ニ傾クモ。融 解液注入间數重ナル二從七筫血，恢 復中止七ラル・ニ及ビ依然トシテ多 數二出現スルモノナリ，No. 77 二於 テハ有核赤血球ノ出現㖤メテ著明ニシテ殆ンド全經過テ通ジテ多數二出現ス。他ノ動

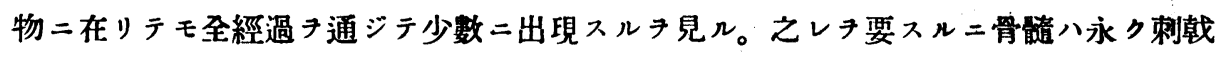
狀態ニ在ルコトチ想像シ得ルナリ。

白血球數 /變化。

全經過フ通ジテ增多症或八減少㱏不規則二出現シ一定，變化き見出シ難シ。No. 79 二在リテ八極メテ著名ナル白血球減少症ヨ見タリ。 

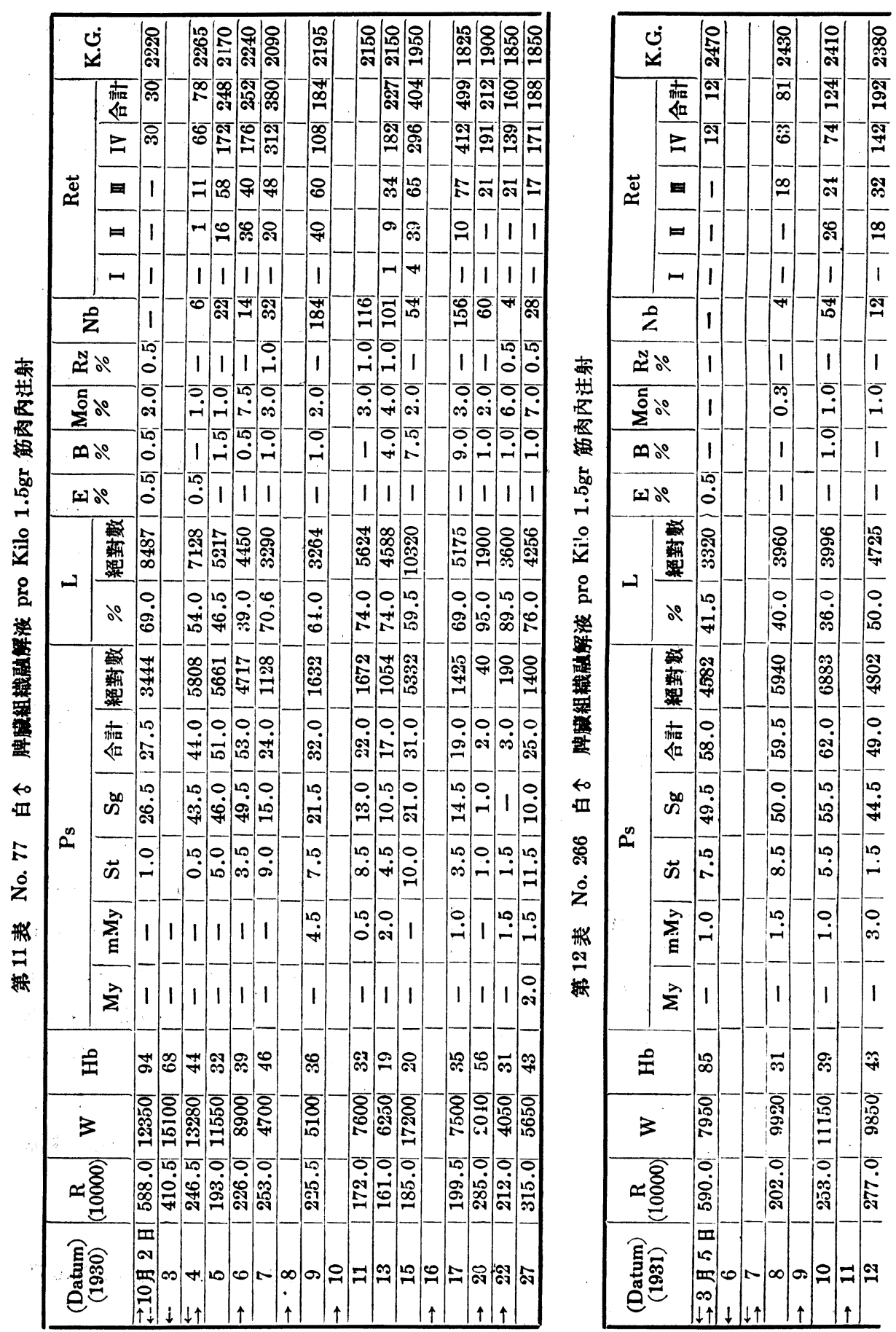


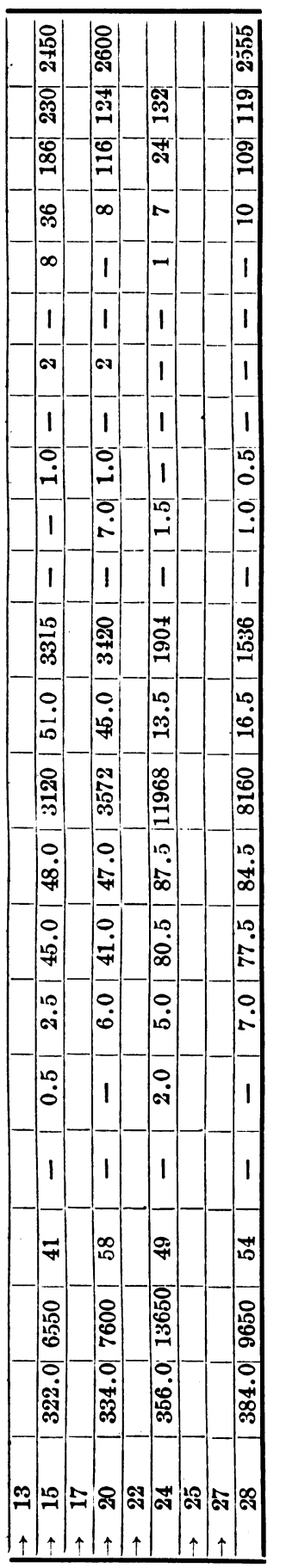

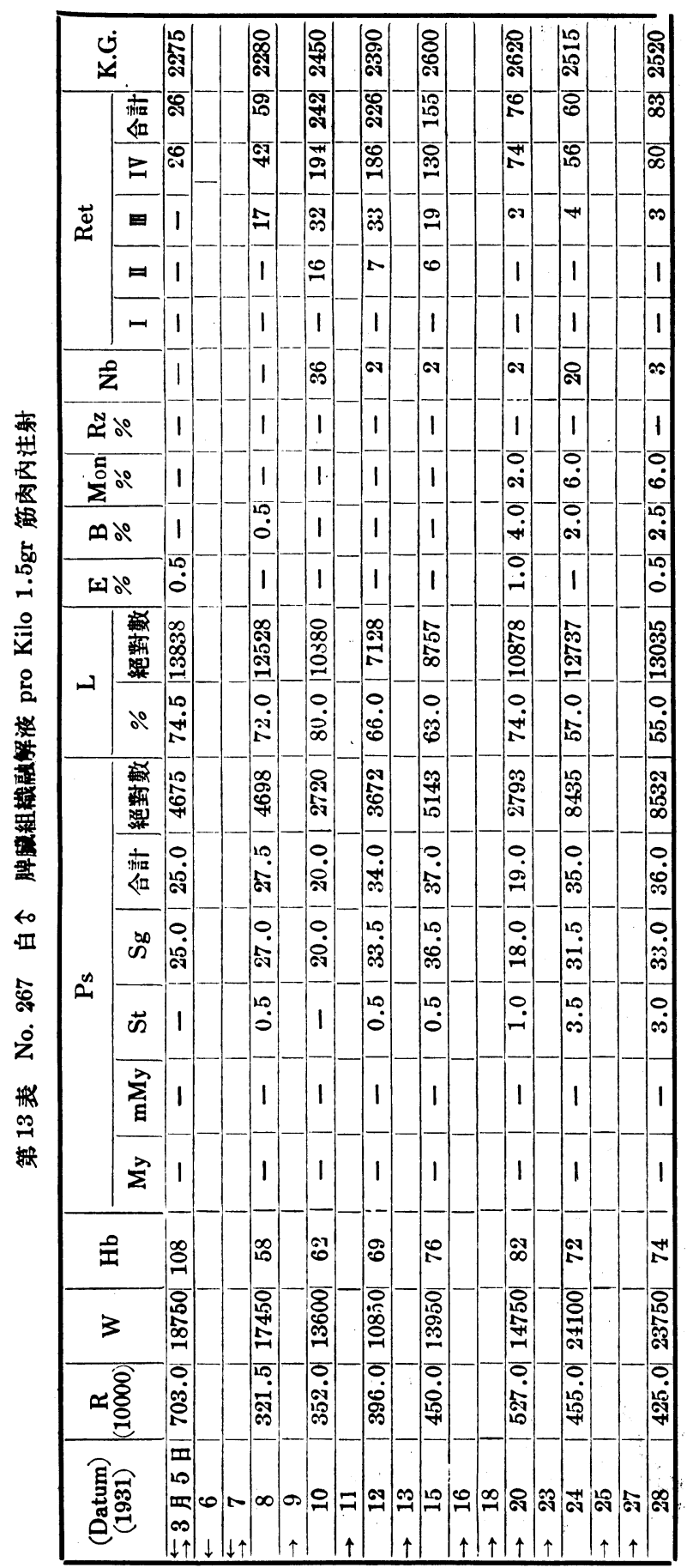


白血球各型變化。

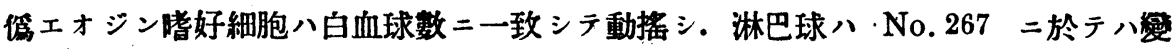
化ナク. 他ノ動物二於テハ減少二傊キ恢復二向フコトナシ。エオジン嗜好細胞及ビ刺

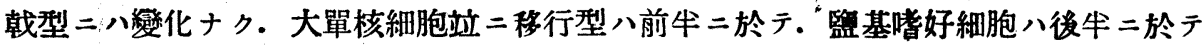
著明二增加セリ。

網狀赤血球ノ消長。

初期二於テ著名二增加セル後一時減少二傾クモ正常二復スルコトナク常二增加ノ狀

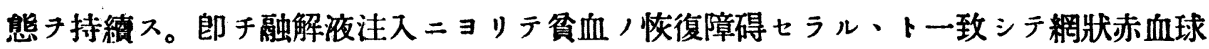
八恢復チ中止シ或ハ反ッテ增量スルモノナリ。倘全經過き通ジテ幼弱型ナル第II型或 八第四型比較的多數二出現七り。之ニヨリテ骨䯕八貧血二應ジテ永ク强キ刺戟狀態二 在ルコトチ想像シ得ベシ。

\section{第三節 筋肉組織蒸餾水自家融解液筋肉內泩射賽驗}

第 9 圖 筋肉組糡融解液 pro Kilo $0.5 \mathrm{gr}$ 注射

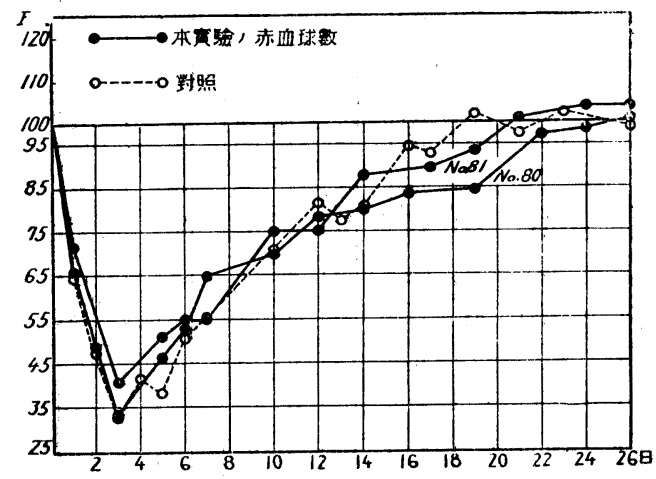

第 10 圆 筋肉組糡融解液 pro Kilo $0.5 \mathrm{gr}$ 注射

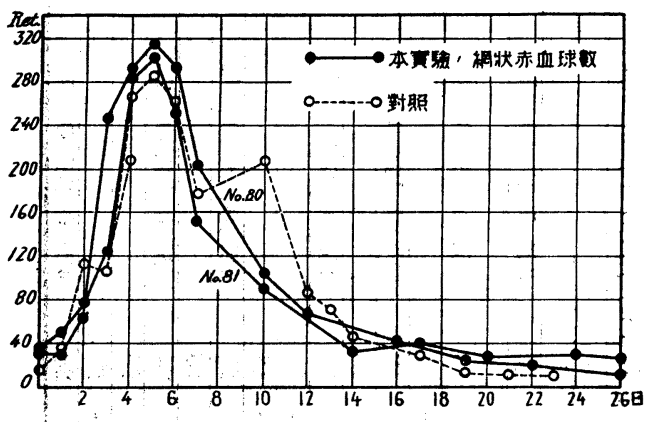

I Pro Kilo $0.5 \mathrm{gr}$ 注射 赤血球數, 恢復狀態。 20-26 日目二正常二恢復 $下$ ，即 對照湶血動物，恢復曲線二彷栃夕 リ。

血色素量，恢復狀態。

略 ? 赤血球二一致シテ恢復二向 7 。

赤血球ノ形態的戀化。

對照洴血動物，變化ト大差ナ シ。

白血球數, 變化。

第一次的增多症二次イデ軾微ナ 几動播キ示シッ、經過ス。 白血球各型/数化。

篇エオジン殗好細胞八白血球數 ニ一致シテ整度/動搖キ示シツ、 經過 ス。 淋巴球八第一次的增多应 二一致シテ俥度二增加シ間モナク 
第 14 表 No. 80 白令 筋肉組斌

\begin{tabular}{|c|c|c|c|c|c|c|c|c|c|c|}
\hline \multirow{2}{*}{$\begin{array}{c}\text { (Datum) } \\
(1930)\end{array}$} & \multirow{2}{*}{$\underset{(10000)}{\mathbf{R}}$} & \multirow{2}{*}{ W } & \multirow{2}{*}{$\mathbf{H b}$} & \multicolumn{6}{|c|}{ Ps } & \multirow{2}{*}{$\frac{\mathrm{L}}{\%}$} \\
\hline & & & & My & $\mathbf{m M y}$ & St & $\mathrm{Sg}$ & 合計 & 絕對數 & \\
\hline$\leftrightarrows 10$ 月15日 & 638.5 & 6650 & 90 & - & - & 1.5 & 30.5 & 32.0 & 2112 & 62.0 \\
\hline$\rightarrow \quad 16$ & $4: 1.5$ & 9750 & 68 & - & - & 2.5 & 40.0 & 42.5 & 4074 & 48.5 \\
\hline \multirow[t]{2}{*}{17} & 279.5 & 10600 & 42 & - & - & 2.0 & 50.5 & 52.5 & 5512 & 40.5 \\
\hline & 215.5 & 13600 & 31 & - & - & 3.5 & 50.0 & 53.5 & 7208 & 28.0 \\
\hline \multicolumn{11}{|l|}{$\rightarrow \quad 19$} \\
\hline 20 & 299.5 & 15200 & 48 & - & - & 3.0 & 41.5 & 43.5 & 6836 & 50.0 \\
\hline$\rightarrow \quad 21$ & 339.5 & 10150 & 56 & - & - & 2.5 & 39.5 & 42.0 & 4242 & 51.0 \\
\hline 22 & 416.5 & 6600 & 65 & - & - & 1.0 & 28.5 & 29.5 & 1914 & 60.5 \\
\hline$\rightarrow \quad 23$ & & & & & & & & & & \\
\hline$\rightarrow \quad 25$ & 456.0 & 6300 & 75 & - & - & 0.5 & 38.0 & 38.5 & 2394 & 51.0 \\
\hline$\rightarrow \quad 27$ & 497.5 & 6650 & 74 & - & - & 1.5 & 31.0 & 32.5 & 2112 & 60.5 \\
\hline$\rightarrow \quad 29$ & 536.0 & & 71.0 & - & - & & & & & \\
\hline$\rightarrow \quad 31$ & 541.0 & 7150 & 72 & - & - & 0.5 & 40.5 & 41.0 & 2911 & 51.0 \\
\hline 11月 3 日 & 552.0 & 9910 & 75 & - & - & 1.0 & 38.5 & 39.5 & 3865 & 55.0 \\
\hline 6 & 5.71 .0 & 8740 & 80 & - & - & 0.5 & 26.5 & 27.0 & 2621 & 65.5 \\
\hline 8 & 629.5 & & 84 & & & & & & & \\
\hline 10 & $6+4.0$ & 10950 & 83 & - & - & 2.0 & 25.5 & 27.5 & 2943 & 65.0 \\
\hline
\end{tabular}

第 15 表 No. 81 白占筋肉組榓

\begin{tabular}{|c|c|c|c|c|c|c|c|c|c|c|}
\hline \multirow{2}{*}{$\begin{array}{c}\text { (Datum) } \\
(1930)\end{array}$} & \multirow{2}{*}{$\underset{(10000)}{\mathbf{R}}$} & \multirow{2}{*}{$\mathbf{W}$} & \multirow{2}{*}{$\mathrm{Hb}$} & \multicolumn{6}{|c|}{ Ps } & \multirow{2}{*}{$\frac{\mathrm{L}}{\%}$} \\
\hline & & & & My & $\mathbf{m M y}$ & St & $\mathrm{Sg}$ & 合計 & 絕對數 & \\
\hline$\rightrightarrows 10$ 月 15 日 & 641.0 & 7850 & 87 & - & - & 0.5 & 37.0 & 37.5 & 2886 & 57.5 \\
\hline$\leftarrow 16$ & 462.5 & 10850 & 70 & - & - & 1.0 & 23.5 & 24.5 & 2592 & 68.5 \\
\hline$\leftrightarrows \quad 17$ & 311.5 & 7450 & 51 & - & - & 0.5 & 33.0 & 33.5 & 2442 & 59.5 \\
\hline 1.9 & 270.5 & 10850 & 45 & - & - & 2.5 & 44.5 & $47 . n$ & 5076 & 47.5 \\
\hline$\rightarrow \quad 19$ & & & & & & & & & & \\
\hline 20 & 334.5 & 11950 & 65 & & & & & & & \\
\hline$\rightarrow \quad 21$ & 417.5 & 12400 & 66 & - & - & 1.0 & 27.5 & 28.5 & 3472 & 65.0 \\
\hline 23 & 418.5 & 5400 & 64 & & & & & & & \\
\hline$\rightarrow \quad 23$ & & & & & & & & & & \\
\hline$\rightarrow \quad 25$ & 491.5 & 5500 & 75 & - & - & 1.5 & 30.5 & 32.0 & 1760 & 60.0 \\
\hline$\rightarrow \quad 27$ & 495.0 & 7550 & 75 & & & & & & & \\
\hline$\rightarrow \quad 29$ & 565.0 & & 83 & - & - & 1.0 & 37.5 & 38.5 & & 60.5 \\
\hline$\rightarrow 11$ 月 1 日 & 581.0 & 6650 & 85 & - & - & 0.4 & 40.0 & 40.5 & 2640 & 50.5 \\
\hline $\mathbf{3}$ & 603.0 & 7820 & 88 & & & & & & & \\
\hline 5 & 651.5 & 6740 & 89 & - & - & 0.5 & 39.5 & 40.0 & 2680 & 55.0 \\
\hline 8 & 672.0 & 7950 & 90 & - & - & 1.0 & 35.5 & 36.5 & 2844 & 55.5 \\
\hline 10 & $666^{\circ} 0$ & 8320 & 90 & - & - & 0.5 & 39.0 & 39.5 & 3239 & 55.5 \\
\hline
\end{tabular}


慗解液 pro Kilo 0.5gr 筋肉内注射

\begin{tabular}{|c|c|c|c|c|c|c|c|c|c|c|c|}
\hline \multirow{2}{*}{$\overline{\mid}$} & \multirow{2}{*}{$\begin{array}{l}\mathbf{E} \\
\%\end{array}$} & \multirow{2}{*}{$\begin{array}{l}\mathbf{B} \\
\%\end{array}$} & \multirow{2}{*}{$\underset{\%}{\text { Mon }}$} & \multirow{2}{*}{$\begin{array}{l}\mathbf{R z} \\
\%\end{array}$} & \multirow{2}{*}{$\mathrm{Nb}$} & \multicolumn{5}{|c|}{ Ret } & \multirow{2}{*}{ K.G. } \\
\hline & & & & & & I & II & III & IV & 合計 & \\
\hline 4090 & 0.5 & 2.5 & 2.5 & 0.5 & - & - & - & - & 28 & 28 & 2640 \\
\hline 4656 & 0.5 & 3.5 & 5.0 & - & 1 & - & - & - & 32 & 32 & 2700 \\
\hline 4240 & 0.5 & 2.5 & 4.0 & - & 1 & - & 3 & 8 & 52 & 63 & $26: 0$ \\
\hline \multirow[t]{2}{*}{$\overline{5168}$} & - & 5.0 & 2.5 & 0.5 & 4 & - & 15 & 41 & 190 & 246 & 2580 \\
\hline & & & & & & - & 29 & 52 & 210 & 291 & \\
\hline 7600 & - & 3.0 & 3.5 & - & 7 & - & 17 & $\overline{48}$ & 250 & 315 & 2550 \\
\hline 5151 & - & 2.5 & 5.0 & - & 1 & - & 9 & 24 & 260 & 293 & 2490 \\
\hline 3960 & 0.5 & 5.5 & 4.0 & - & - & $=$ & - & 9 & 192 & 201 & $25: 0$ \\
\hline$\overline{3213}$ & 0.5 & 5.5 & 4.5 & - & - & - & - & $\overline{2}$ & 101 & 103 & 2610 \\
\hline \multirow[t]{2}{*}{8960} & 0.5 & 3.5 & 2.5 & 0.5 & - & - & - & - & 64 & 64 & 2650 \\
\hline & & & & & & & & & & & 2700 \\
\hline 3621 & - & 3.5 & 4.0 & 0.5 & - & - & - & - & 41 & 41 & 2710 \\
\hline 5445 & 0.5 & 2.5 & 0.5 & - & - & - & - & - & 23 & 23 & 2650 \\
\hline \multirow[t]{2}{*}{5655} & 0.5 & 2.0 & 3.5 & 1.5 & - & - & - & - & 20 & 20 & 2700 \\
\hline & & & & & & & & & & & 2695 \\
\hline 7065 & 0.5 & 3.0 & 2.5 & 1.5 & - & - & - & - & 13 & 13 & 2750 \\
\hline
\end{tabular}

融解液 pro Kilo 0.5gr 筋内内注射

\begin{tabular}{|c|c|c|c|c|c|c|c|c|c|c|c|}
\hline \multirow[b]{2}{*}{ |絕對數 } & \multirow{2}{*}{$\begin{array}{l}\mathbf{E} \\
\%\end{array}$} & \multirow{2}{*}{$\begin{array}{l}\mathbf{B} \\
\%\end{array}$} & \multirow{2}{*}{$\underset{\%}{\text { Mon }}$} & \multirow{2}{*}{$\begin{array}{l}\mathbf{R z} \\
\%\end{array}$} & \multirow{2}{*}{$\mathrm{Nb}$} & \multicolumn{5}{|c|}{ Ret } & \multirow{2}{*}{ K.G } \\
\hline & & & & & & I & II & III & IV & 合計 & \\
\hline 4446 & 0.5 & 2.0 & 1.5 & 1.0 & - & - & - & - & 35 & 35 & 2350 \\
\hline 7344 & 0.5 & 3.0 & 0.5 & 0.5 & - & - & - & 3 & 42 & $\overline{45}$ & 2270 \\
\hline 4366 & - & 2.5 & 4.0 & 0.5 & - & - & - & 10 & 68 & 78 & 2210 \\
\hline \multirow[t]{3}{*}{5076} & 1.0 & 1.0 & 2.0 & 0.5 & 4 &.- & 9 & 17 & 96 & 122 & 2240 \\
\hline & & & & & & - & 26 & 50 & 211 & 287 & \\
\hline & & & & & & - & 27 & 53 & 221 & 301 & $22 \div 0$ \\
\hline \multirow[t]{2}{*}{8060} & 1.5 & 0.5 & 4.0 & 0.5 & 1 & - & 9 & 66 & 180 & 255 & \\
\hline & & & & & & - & - & 31 & 120 & 151 & 2250 \\
\hline \multirow[t]{3}{*}{3300} & - & 2.5 & 5.0 & 0.5 & - & - & - & - & 91 & 91 & $\overline{2275}$ \\
\hline & & & & & & & & & & & 2330 \\
\hline & - & 0.1 & 2.0 & 1.0 & - & - & - & - & 37 & 37 & 2320 \\
\hline \multirow[t]{2}{*}{3300} & 0.5 & 2.0 & 5.5 & 1.0 & - & - & - & - & 40 & 40 & 2320 \\
\hline & & & & & & & & & & & 2400 \\
\hline 3685 & - & 2.5 & 2.0 & 0.5 & - & - & - & - & 33 & 33 & 2410 \\
\hline 4345 & - & 4.0 & 3.5 & 0.5 & - & - & - & - & 27 & 27 & 2450 \\
\hline 4565 & 0.5 & 2.5 & 2.5 & - & - & - & - & - & 23 & 23 & 2400 \\
\hline
\end{tabular}


正常ニ復シタル後比較的動搖ナク經過セリ。エオジン嘫好細胞及ビ刺戟型ニ八變化ナ ク. 監基嗜好細胞. 大單核細胞泣二移行型八第一次的增多症二際シ共二增加スルモ以 媵八正常二復ス。

湅狀赤血球 /消長。

5 日目二夫々最高値 $301-315$ 二達ス。

其 / 經過略 3 嫁血動物二一致ス。

II $1.5 \mathrm{gr}$ 注射

第 11

圆

筋肉組糡融解液 pro Kilo $1.5 \mathrm{gr}$ 注射

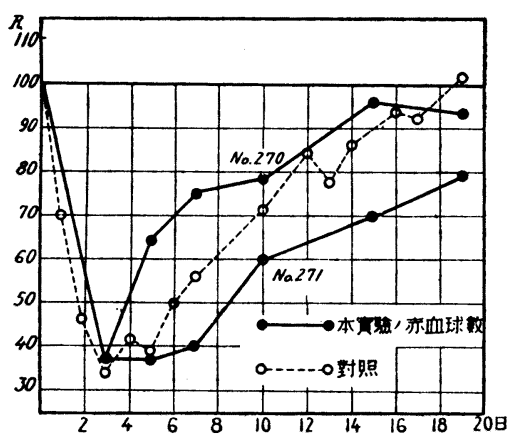

第 12 圆

筋肉組糡融解液 pro Kilo $1.5 \mathrm{gr}$ 注射

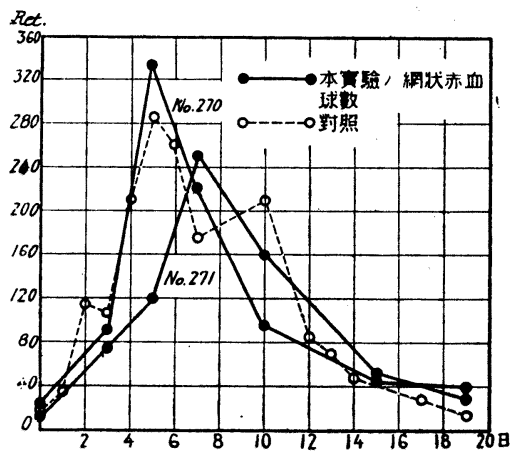

赤血球數ノ恢復狀態。

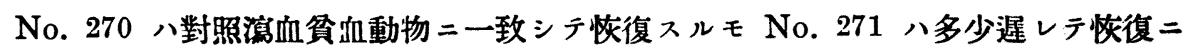
向フ。然レドモ恢復き中止スルガ如キコトナシ。

血色素量, 恢復狀態。

赤血球二一致シテ恢復入。

赤血球 / 形態的篎化。

對照演血動物ト異レル所ナシ。

白血球數, 變化。

第一次的增多症二次イデ轅微ナル動㨋タ示シツ、經過ス。

白血球各型/變化。

篇エオジン脂好細胞八第一次的增多症二一致シテ增加シタル後動㧨シツ、經過シ。 淋巴球八第一次的增多症二際 三輕度增加シタル後渐次減少二傾キ正常以下二降ルコト

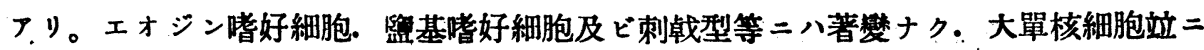
移行型八第一次的增多症二一致シテ百分本. 絕對數共二增加ス。 
第 16 表 No. 270 白含筋肉組

\begin{tabular}{|c|c|c|c|c|c|c|c|c|c|c|}
\hline \multirow{2}{*}{$\underset{(1931)}{\text { (Datum) }}$} & \multirow{2}{*}{$\underset{(10000)}{\mathbf{R}}$} & \multirow{2}{*}{$\mathbf{W}$} & \multirow{2}{*}{$\mathrm{Ab}$} & \multicolumn{6}{|c|}{ Ps } & \multirow{2}{*}{$\frac{\mathbf{L}}{\%}$} \\
\hline & & & & My & $\mathrm{mMp}$ & St & $\mathrm{Sg}$ & 合計 & 絕對数 & \\
\hline$\leftrightarrows 3$ 月13日 & 548.0 & $79 \dot{0} 0$ & 81 & - & - & - & 22.0 & 22.0 & 1738 & 72.0 \\
\hline$\leftarrow 14$ & & & & & & & & & & \\
\hline \multicolumn{11}{|l|}{$\leftrightarrows \quad 15$} \\
\hline 16 & 205.0 & 13500 & 41 & - & - & 2.0 & 40.0 & 42.0 & 5670 & 60.5 \\
\hline \multicolumn{11}{|l|}{$\rightarrow \quad 17$} \\
\hline 18 & 350.0 & 14800 & 53 & - & - & 2.5 & 49.5 & 52.0 & 7696 & 41.0 \\
\hline \multicolumn{11}{|l|}{$\rightarrow \quad 19$} \\
\hline 20 & 401.0 & 7850 & 60 & - & - & 1.0 & 21.5 & 12.5 & 1738 & 70.5 \\
\hline \multicolumn{11}{|l|}{$\rightarrow \quad 22$} \\
\hline 23 & 431.0 & 5500 & 74 & - & - & - & 32.5 & 32.5 & 1760 & 67.5 \\
\hline \multicolumn{11}{|l|}{$\rightarrow \quad 24$} \\
\hline \multicolumn{11}{|l|}{$\rightarrow \quad 27$} \\
\hline 23 & 528.0 & 10150 & 71 & - & - & 1.0 & 43.0 & 44.0 & $4+44$ & 51.5 \\
\hline \multicolumn{11}{|l|}{$\rightarrow \quad 29$} \\
\hline \multicolumn{11}{|l|}{$\rightarrow \quad 31$} \\
\hline 4 月 1 日 & 513.0 & 12550 & 76 & - & - & - & 63.0 & 63.0 & 7375 & 34.0 \\
\hline
\end{tabular}

第 17 表 No. 271 白全 筋肉組

\begin{tabular}{|c|c|c|c|c|c|c|c|c|c|c|}
\hline \multirow{2}{*}{$\begin{array}{c}\text { (Datum) } \\
(1931)\end{array}$} & \multirow{2}{*}{$\underset{(10000)}{\mathbf{R}}$} & \multirow{2}{*}{ W } & \multirow{2}{*}{$\mathrm{Hb}$} & \multicolumn{6}{|c|}{ Ps } & \multirow{2}{*}{$\frac{\mathbf{L}}{\%}$} \\
\hline & & & & My & $\mathrm{mMy}$ & St & $\mathbf{S}_{\alpha}$ & 合計 & 絕對數 & \\
\hline$\leftrightarrows 3$ 月13日 & 793.0 & 13600 & 114 & - & - & 0.5 & 37.5 & 38.0 & 5168 & 59.0 \\
\hline$\leftarrow 14$ & & & & & & & & & & \\
\hline$\stackrel{\leftarrow}{\rightarrow} \quad 15$ & 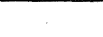 & & & & & & & & & \\
\hline 16 & 295.0 & 15900 & 59 & - & - & 1.5 & 38.0 & 39.5 & 6360 & 58.5 \\
\hline$\rightarrow \quad 17$ & & & & & & & & & & \\
\hline 18 & 316.0 & 18350 & 56 & - & - & 1.0 & 54.0 & 55.0 & 10065 & 43.0 \\
\hline$\rightarrow \quad 20$ & 395.0 & 14300 & 62 & - & - & 1.0 & 40.5 & 41.5 & 5863 & 54.5 \\
\hline$\rightarrow \quad 22$ & & & & & & & & & & \\
\hline 23 & 468.0 & 5550 & 79 & - & - & 2.0 & 25.0 & 27.0 & 1485 & 72.5 \\
\hline$\rightarrow \quad 24$ & & & & & & & & & & \\
\hline$\rightarrow \quad 27$ & & & & & & & & & & \\
\hline 28 & 548.0 & 6600 & 96 & - & - & - & 34.0 & 34.0 & 2244 & 53.5 \\
\hline$\rightarrow \quad 29$ & & & & & & & & & & \\
\hline$\rightarrow \quad 31$ & & & & & & & & & & \\
\hline 4 月1日 & 610.0 & 9600 & 94 & - & - & - & 20.0 & 20.0 & 1920 & 74.0 \\
\hline
\end{tabular}

棢狀赤血球, 消長。

No. $270 八 5$ 日目二. No. 271 八 7 日目二夫々最高值 248,335 二達シ南チ二正常

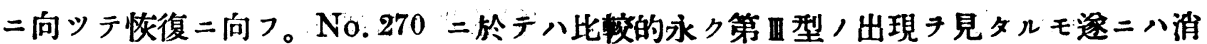


絿致野液 pro Kilo $1.5 \mathrm{gr}$ 注射

\begin{tabular}{|c|c|c|c|c|c|c|c|c|c|c|c|}
\hline \multirow[b]{2}{*}{ 絕對數 } & \multirow{2}{*}{$\begin{array}{l}\mathbf{E} \\
\%\end{array}$} & \multirow{2}{*}{$\begin{array}{l}\text { B } \\
\%\end{array}$} & \multirow{2}{*}{$\underset{\%}{\text { Mon }}$} & \multirow{2}{*}{$\begin{array}{l}\mathrm{Rz} \\
\%\end{array}$} & \multirow{2}{*}{$\mathrm{Nb}$} & \multicolumn{5}{|c|}{ Ret } & \multirow{2}{*}{ K.G. } \\
\hline & & & & & & I & II & III & IV & 合計 & \\
\hline 5688 & 1.0 & 2.0 & 3.0 & - & - & - & - & - & 21 & 21 & 2265 \\
\hline & & & & & & & & & & & \\
\hline & & & & & & & & & & & is \\
\hline 8100 & - & 1.0 & 0.5 & - & 4 & - & 2 & 15 & 72 & 89 & 2350 \\
\hline 6068 & - & - & 7.0 & - & 88 & 4 & 20 & 41 & 272 & 335 & 2420 \\
\hline 5530 & 1.0 & 2.5 & 3.5 & - & 9 & - & 19 & 32 & 169 & 220 & 2400 \\
\hline 3685 & - & - & - & - & 2 & - & - & 5 & 91 & 96 & 2410 \\
\hline 5151 & 0.5 & 3.0 & 1.0 & - & - & - & - & 1 & 41 & 42 & $24 \overline{5} 5$ \\
\hline & & & & & & & & & & & \\
\hline 4250 & - & 1.0 & 2.0 & - & - & - & - & 1 & 40 & 41 & 2510 \\
\hline
\end{tabular}

糡融解液 pro Kilo $1.5 \mathrm{gr}$ 注射

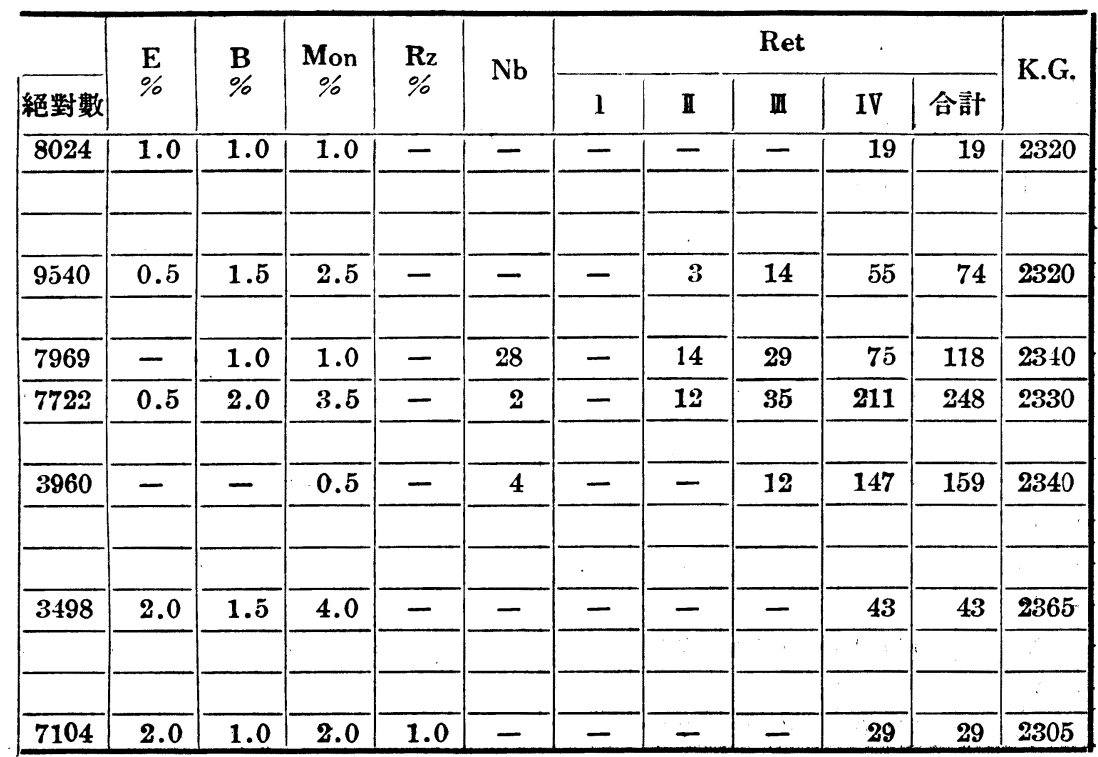

失セリ。

第四節 淋巴腺蒸餾水自家融解液 (pro Kilo 0.5gr) 筋肉內注射 
第 18 表 No. 258 白㑒 淋巴腺自家

\begin{tabular}{|c|c|c|c|c|c|c|c|c|c|c|}
\hline \multirow{2}{*}{$\begin{array}{c}\text { (Datum) } \\
(1931)\end{array}$} & \multirow{2}{*}{$\underset{(10000)}{\mathbf{R}}$} & \multirow{2}{*}{ W } & \multirow{2}{*}{$\mathbf{H b}$} & \multicolumn{6}{|c|}{ Ps } & \multirow{2}{*}{$\frac{\mathbf{L}}{\%}$} \\
\hline & & & & My & $\mathbf{m M y}$ & St & $\mathrm{Sg}$ & 合計 & 絕對數 & \\
\hline$\stackrel{\leftrightarrows}{\leftrightarrows} 2$ 月 4 日 & 680.0 & 7800 & 97 & - & - & - & 18.5 & 18.5 & 1443 & 81.0 \\
\hline \multicolumn{11}{|l|}{$\leftarrow 5$} \\
\hline \multicolumn{11}{|l|}{$\stackrel{6}{\leftrightarrows} 6$} \\
\hline 7 & 289.0 & 8500 & 44 & - & - & 1.0 & 26.5 & 27.5 & 2252 & 70.0 \\
\hline \multicolumn{11}{|l|}{$\rightarrow \quad 8$} \\
\hline 9 & 352.0 & 11150 & 51 & - & - & 1.0 & 40.0 & 41.0 & 4440 & 49.5 \\
\hline \multicolumn{11}{|l|}{$\rightarrow \quad 10$} \\
\hline 11 & 501.0 & 6450 & 63 & - & - & - & 14.0 & 14.0 & 896 & 80.5 \\
\hline \multicolumn{11}{|l|}{$\rightarrow \quad 12$} \\
\hline$\rightarrow \quad 14$ & 557.0 & 5250 & 71 & - & - & - & 23.0 & 23.0 & 1196 & 74.5 \\
\hline \multicolumn{11}{|l|}{$\rightarrow \quad 16$} \\
\hline$\rightarrow \quad 18$ & 579.0 & 5050 & 76 & - & - & 0.5 & 35.5 & 36.0 & 1775 & 62.0 \\
\hline \multicolumn{11}{|l|}{$\rightarrow \quad 20$} \\
\hline 21 & 621.0 & & 80 & & & & & & & \\
\hline 23 & 678.0 & 5850 & 85 & & & & & & & \\
\hline 26 & 685.0 & & 95 & & & & & & & \\
\hline
\end{tabular}

第 19 表 No. 259 白古 淋巴腺自家

\begin{tabular}{|c|c|c|c|c|c|c|c|c|c|c|}
\hline \multirow{2}{*}{$\begin{array}{c}\text { (Datum) } \\
(1931)\end{array}$} & \multirow{2}{*}{$\underset{(10000)}{\mathbf{R}}$} & \multirow{2}{*}{$\mathbf{W}$} & \multirow{2}{*}{$\mathrm{Hb}$} & \multicolumn{6}{|c|}{ Ps } & \multirow{2}{*}{$\frac{\mathbf{L}}{\%}$} \\
\hline & & & & My & $\mathrm{mMy}$ & St & $\mathrm{Sg}$ & 合計 & 絕對數 & \\
\hline$\stackrel{5}{\leftrightarrows} 2$ 月 4 日 & 676.0 & 6700 & 100 & - & - & 1.5 & 53.5 & 55.0 & 3584 & 41.0 \\
\hline$\leftarrow 5$ & & & & & & & & & & \\
\hline \multicolumn{11}{|l|}{$\leftrightarrows 6$} \\
\hline 7 & 274.0 & 14200 & 43 & - & - & 2.5 & 35.5 & 38.0 & 5041 & 56.0 \\
\hline \multicolumn{11}{|l|}{$\rightarrow \quad 8$} \\
\hline 9 & 324.0 & 8300 & 50 & - & - & 2.0 & 22.0 & 24.0 & 1826 & 68.0 \\
\hline \multicolumn{11}{|l|}{$\rightarrow \quad 10$} \\
\hline 11 & 353.0 & 8500 & 65 & - & - & 0.5 & 25.5 & 26.0 & 2167 & 64.0 \\
\hline \multicolumn{11}{|l|}{$\rightarrow \quad 12$} \\
\hline$\rightarrow \quad 14$ & 439.0 & 8950 & 70 & - & - & 1.0 & 65.5 & 66.5 & 5829 & 25.5 \\
\hline \multicolumn{11}{|l|}{$\rightarrow \quad 16$} \\
\hline$\rightarrow \quad 18$ & 480.0 & 4450 & 72 & - & - & - & 50.5 & 50.5 & 2222 & 41.5 \\
\hline \multicolumn{11}{|l|}{$\rightarrow \quad 20$} \\
\hline 23 & 571.0 & 6250 & 78 & - & - & 0.5 & 59.0 & 59.5 & 3658 & 27.0 \\
\hline
\end{tabular}

赤血球數ノ恢復狀態。

大體二於テ對照渲血動物ノ恢復曲線二一致シテ恢復ス。 血色素量, 恢復狀態。 
融解液 pro Kilo $0.5 \mathrm{gr}$ 筋肉内注射

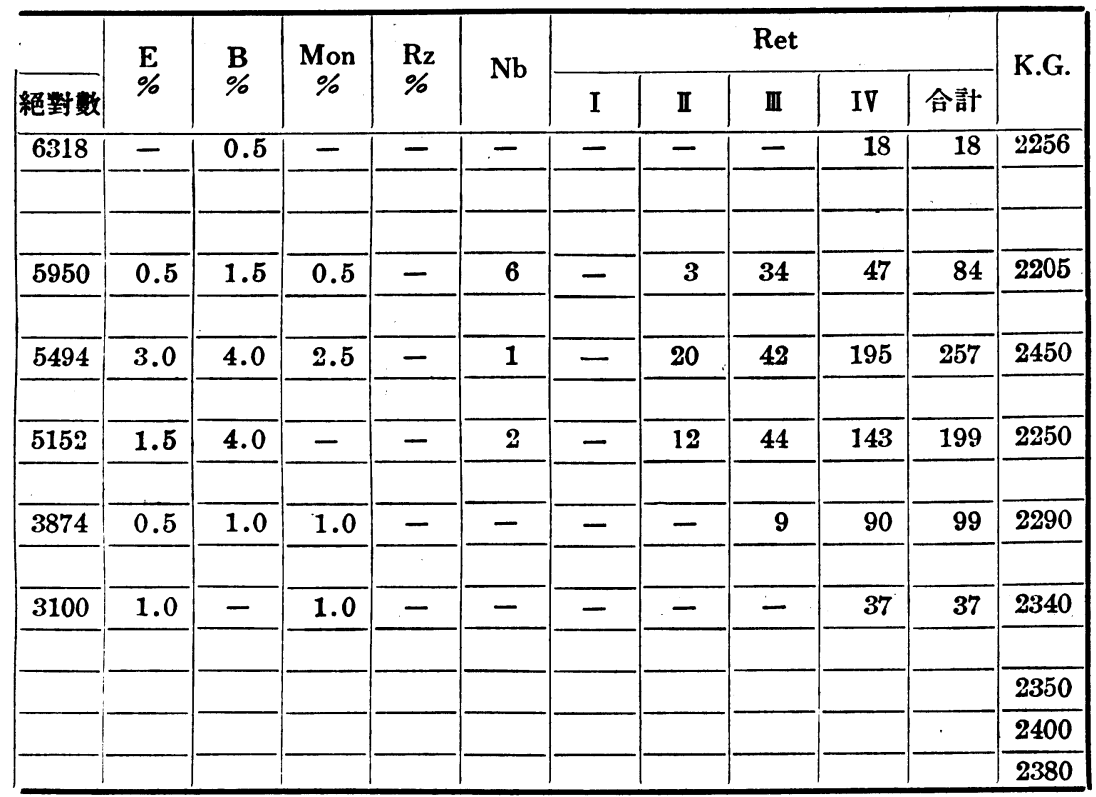

融解液 pro Kilo 0.5gr 筋肉內注射

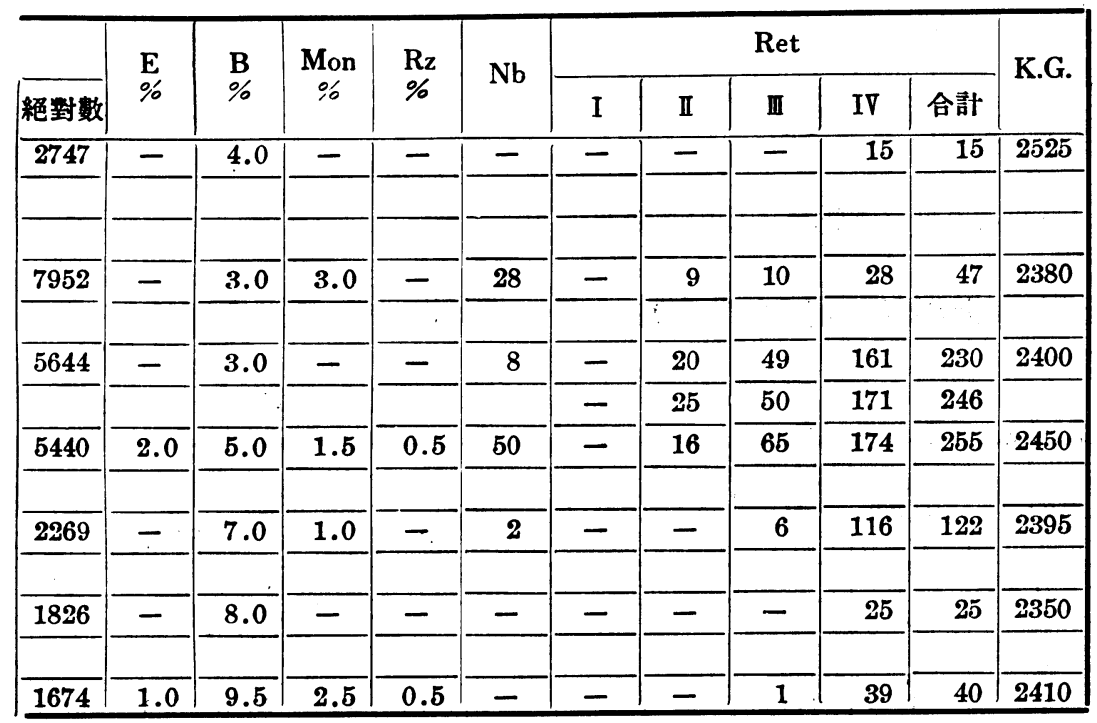

略了赤血球數ノ恢復二伴ヒテ恢復ス。

赤血球，形態的等化。

對照瀉血貿血動物ト異ル所ナシ。 


\section{第 13 圆}

淋巴腺融解液 pro Kito 0.5gr 筋肉肉注射

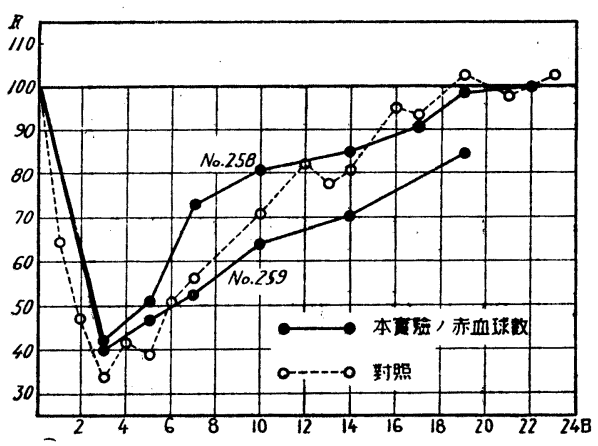

第 14 圆

淋巴腺融解液 pro Kilo 0.5gr 筋肉內注射

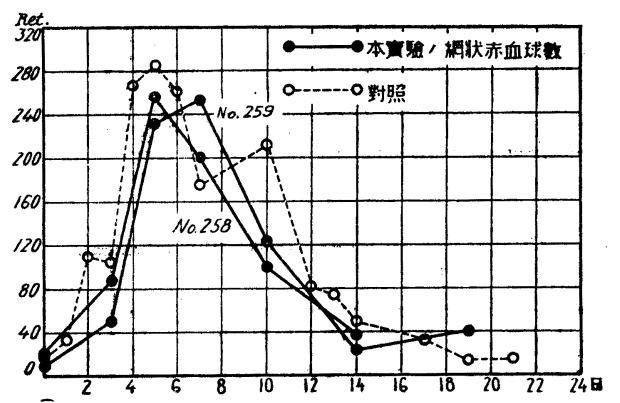

白血球数，變化。

第一次的增多应二次イデ增多症或 八減少症不規則二現レ一定ノ見解 把握 シ難シ。

白血球各型, 變化。

俘エオジン睹好細胞八第一次的增 多应二一致シテ增加シ. 以後强っ動 搖シツ、經過ス。淋巴球八No. 258 二於テハ初メヨリ. No. 259 二於テ 八第一次的增多症二件七一時增加 三 テョリ一路減少二傾ケリ。No. 259

二於テ一時著名ナル「エオジン搘好 細胞ノ增加テ見タルコトアリ。監基 啄好細胞八常二增加 シ. No. 259 二 於テ八著名ナル增加テ見ル。大單核 細胞㬵二移行型ハ增加スルモ著名ナ ラズ。

網狀赤血球，消長。 5一6 日目二夫々最高値 $257-246$

二達シ直チ二正常ニ向ツテ恢復ノ徑路キ巡ル。

第五節 肺臟組織蒸餾水自家融解液 (pro Kilo 0.5gr) 筋肉內泩射

第 20 表 No. 260 白令 肺㬴組樴

\begin{tabular}{|c|c|c|c|c|c|c|c|c|c|c|}
\hline \multirow{2}{*}{$\begin{array}{c}\text { (Datum) } \\
(1931)\end{array}$} & \multirow{2}{*}{$\underset{(10000)}{\mathbf{R}}$} & \multirow{2}{*}{$\mathbf{W}$} & \multirow{2}{*}{$\mathrm{Hb}$} & \multicolumn{6}{|c|}{ Ps } & \multirow{2}{*}{$\frac{\mathbf{L}}{\%}$} \\
\hline & & & & My & $\mathbf{m M y}$ & St & Sg & 合計 & 絕對數 & \\
\hline$\stackrel{\leftrightarrows}{\rightarrow} 2$ 月 4 日 & 754.0 & 7000 & 97 & - & - & - & 30.0 & 30.0 & 2100 & 54.0 \\
\hline$\leftarrow 5$ & & & & & & & & & & \\
\hline$\stackrel{\leftrightarrows}{\rightarrow} 6$ & & & & & & & & & & \\
\hline 7 & 282.0 & 11150 & 40 & - & - & 2.0 & 49.5 & 51.5 & 5494 & 46.5 \\
\hline$\rightarrow \quad 8$ & & & & & & & & & & \\
\hline 9 & 396.0 & 7950 & 54 & - & - & 2.5 & 47.5 & 50.0 & 3752 & 48.0 \\
\hline$\rightarrow \quad 10$ & & & & & & & & & & \\
\hline 11 & 414.0 & 5800 & 62 & - & - & 0.5 & 24.5 & 25.0 & 1421 & 68.0 \\
\hline
\end{tabular}




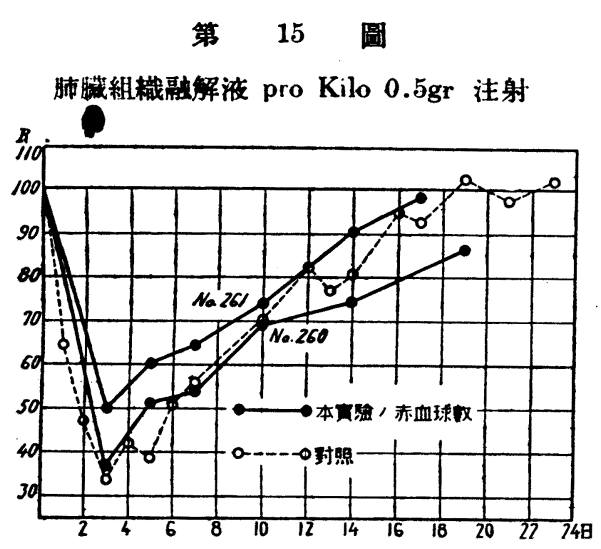

第 16 圆

肺璄組糡融解液 pro Kilo $0.5 \mathrm{gr}$ 注射

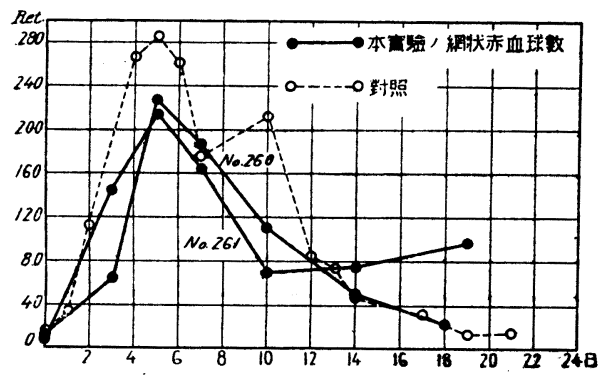

リ多少增加ノ狀態キ持綡セリ。
赤血球数，恢復狀態。

䍈照㴧血動物，恢復曲線二一致 ᄌ。

血色素量/恢復狀態。 赤血球二一致シテ恢復ス。 赤血球 ノ形態的變化。 對照㴼血動物ト異ナル所ナシ。 白血球數ノ變化。

第一次的增多症二次イデ軗微ナル 動接キ示シッ、經過ス。 白血球各型，變化。

稨エオジン脄好細胞ハ白血球數二 一致シテ動㨸シ. 淋巴球ハ湭血後一 時增加スルモ間モナク正常二復セ リ。

網狀赤血球，消長。

演血後 5 日目二夫々最高値 225 , 214 二達シ直チニ下降シテ正常二復 ス. No. 261 二於テハ 10 日目頃

融解液 pro Kilo $0.5 \mathrm{gr}$ 筋肉內注射

\begin{tabular}{|c|c|c|c|c|c|c|c|c|c|c|c|}
\hline \multirow[b]{2}{*}{ 絕對數 } & \multirow{2}{*}{$\begin{array}{l}\mathbf{E} \\
\%\end{array}$} & \multirow{2}{*}{$\begin{array}{l}\mathbf{B} \\
\%\end{array}$} & \multirow{2}{*}{$\underset{\%}{\text { Mon }}$} & \multirow{2}{*}{$\begin{array}{l}\mathbf{R z} \\
\%\end{array}$} & \multirow{2}{*}{$\mathrm{Nb}$} & \multicolumn{5}{|c|}{ Ret } & \multirow{2}{*}{ K.G. } \\
\hline & & & & & & I & II & 且 & IV & 合計 & \\
\hline 3780 & - & 0.5 & 1.5 & 1.5 & - & - & - & 2 & 13 & 15 & 2140 \\
\hline & & & & & & & & & & & \\
\hline 5161 & - & - & 2.0 & - & 6 & - & 9 & 0 & 52 & ? & 9150 \\
\hline & & & & & & & & & & & בDV \\
\hline 3792 & 1.0 & - & 1.0 & - & 6 & - & 7 & 40 & 178 & 225 & 2165 \\
\hline 3944 & 1.0 & 2.0 & 3.5 & 0.5 & 2 & - & 27 & 31 & 130 & 188 & 2140 \\
\hline
\end{tabular}




\begin{tabular}{|c|c|c|c|c|c|c|c|c|c|c|c|}
\hline \multicolumn{12}{|c|}{$\rightarrow \quad 12$} \\
\hline & 14 & 532.0 & 8750 & $7 I$ & - & - & 0.5 & 31.5 & 32.0 & 2740 & 62.0 \\
\hline \multicolumn{12}{|c|}{$\rightarrow \quad 16$} \\
\hline & $\cdot 18$ & 559.0 & 5000 & 76 & - & - & - & 17.0 & 17.0 & 850 & 75.0 \\
\hline & 19 & & & & & & & & & & . \\
\hline & 21 & 652.0 & & 90 & & & & & & & \\
\hline
\end{tabular}

\begin{tabular}{|c|c|c|c|c|c|c|c|c|c|c|}
\hline \multirow{2}{*}{$\begin{array}{c}\text { (Datum) } \\
(1931)\end{array}$} & \multirow{2}{*}{$\mathbf{R}$} & \multirow{2}{*}{$\mathbf{W}$} & \multirow{2}{*}{$\mathrm{Hb}$} & \multicolumn{6}{|c|}{ Ps } & \multirow{2}{*}{$\frac{\mathbf{L}}{\%}$} \\
\hline & & & & $\mathbf{M y}$ & $\mathbf{m M y}$ & St & Sg & 合計 & 絕對數 & \\
\hline$\leftrightarrows 2$ 月 4 日 & 689.0 & 8550 & 101 & - & - & - & 30.5 & 30.5 & 2592 & 63.5 \\
\hline$\leftarrow 5$ & & & & & & & & & & \\
\hline$\leftrightarrows 6$ & & & & & & & & & & \\
\hline 7 & 347.0 & 44440 & 50 & - & - & 0.5 & 49.5 & 50.0 & 21978 & 38.0 \\
\hline \multicolumn{11}{|l|}{$\rightarrow \quad 8$} \\
\hline 9 & 424.0 & 11150 & 60 & - & - & 4.5 & 49.5 & 54.0 & 5494 & 34.0 \\
\hline \multicolumn{11}{|l|}{$\rightarrow \quad 10$} \\
\hline 11 & 454.0 & 11750 & 68 & - & - & 1.5 & 42.5 & 44.0 & 4972 & 45.0 \\
\hline \multicolumn{11}{|l|}{$\rightarrow \quad 12$} \\
\hline$\rightarrow \quad 14$ & 514.0 & 5850 & 71 & - & - & 1.0 & 50.0 & 51.0 & 2900 & 45.5 \\
\hline \multicolumn{11}{|l|}{$\rightarrow \quad 16$} \\
\hline$\rightarrow \quad 18$ & 644.0 & 6500 & 79 & - & - & - & 41.5 & 41.5 & 2697 & 54.5 \\
\hline \multicolumn{11}{|l|}{$\rightarrow \quad 20$} \\
\hline 21 & 677.5 & & 90 & & & & & & & \\
\hline 23 & 608.0 & 8600 & 89 & - & - & 1.0 & 24.0 & 25.0 & 2064 & 64.0 \\
\hline
\end{tabular}

\section{第四辛 總括竝二券案}

第一項 赤血球, 尜化二就キテ

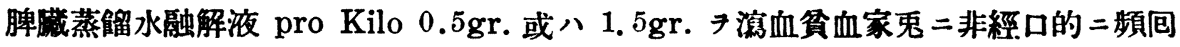
注入スル時八貧血ノ恢復障碍七ラル。而シテ pro Kilo $1.5 \mathrm{gr}$. 場合二ハ極メテ著明 二障碍七ラル。其ノ際流血中ノ網狀赤血球八贫血ト共二永ク增加ノ狀態 持綘シ正常 二復スルコトナシ。之レテ赤血球或八骨䯕細胞融解液大量注入ノ場合卜比較スル時八 甚ダ興味フル事賽ニシテ.共二貿血/恢復著シク障碍セラル、モ。赤血球或ハ骨笓細

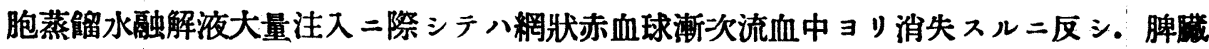

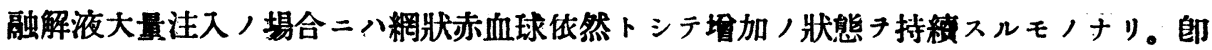
流血中二出現スル粯狀赤血球/態度 $コ$ 考フル二脾满融解液注入二ヨリテ贫血，恢復 障碍七ラル、八赤血球或八骨髄融解液注入，場合／如ク赤血球新生機能抑制七ラル、 篇メニハ非ズト云フタ得ベシ。横森. 後藤氏等八健康家鬼二脾藏乳剂或ハ其ノ越幾斯 


\begin{tabular}{|c|c|c|c|c|c|c|c|c|c|c|c|}
\hline 5394 & 4.0 & 1.0 & 2.0 & - & - & - & - & 20 & 90 & 110 & 2216 \\
\hline 3750 & 6.0 & - & 2.0 & - & - & - & - & - & 46 & 46 & 2230 \\
\hline & & & & & & - & - & - & 21 & 21 & 2230 \\
\hline
\end{tabular}

㽬解液 pro Kilo $0.5 \mathrm{gr}$ 筋肉內注射

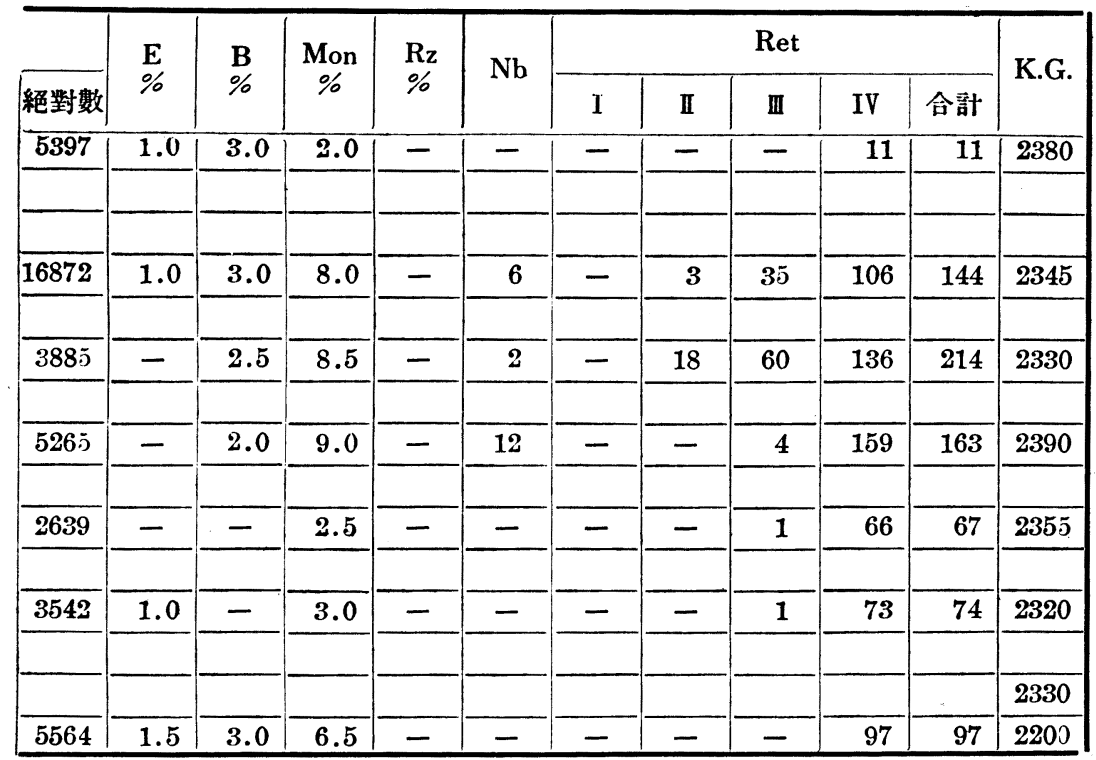

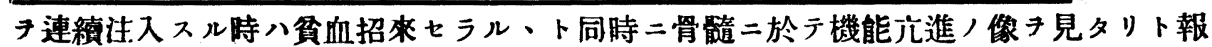
告セルニヨリ一致スィモ其ノ作用機轉八尚不明ナリ。然レドモ官川数授，直接作用， 原理ヨリ脾臟成分八直接二脾藏二作用スルモノニシテ造血機能八第二次的二影䇾き受 クルモノナルコトハ想二難かラザル所ニシテ其/詳綀ハ今媵，研究二俟ツベキモ， ナリ。

旰灌蒸餾水自家虽解液 pro Kilo $0.5 \mathrm{gr}$. 7 速續注入スル時八貧血，恢復多少促進七 ラレタリト思ハル、モノアリタルモ赤血球或八骨䯕融解液適量注入/場合/比二韭 ズ。又恢復期赤血球過多症及ビ粡狀赤血球ノ增加等タ認メザリキ。郎續發性筫血或八

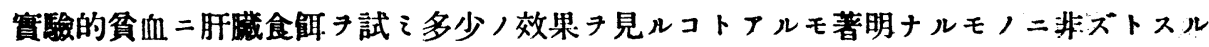
諸學者ノ成績ニ一致スルモノニシテ.之レョ以テ惡性貧血二對スル作用機轉ヨ說明ス 可カラザル八論キ俟タザル所ナリ。然ラバ多少ナリトモ筫血ノ恢復キ促進シタルハ何 フ上于說明ス可キ力。余八所謂官川教授, 唱フルAutohormon，比較的藏器特

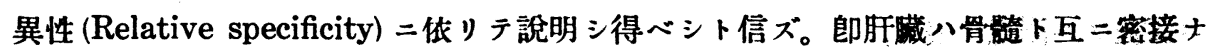




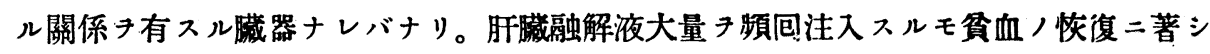
キ影部フ及ボスコトナクヨク恢復ニ向フモノナリ。

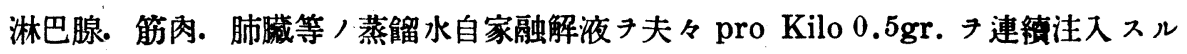

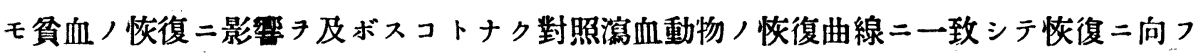
モノナリ。流血中ノ網狀赤血球ニモ著名ナル變化キ認ムルコトナシ。大量き注入スル モ亦貧血ノ恢復き障碍スルガ如キコトナシ。

\section{第二項 白血球/紮化二就キテ}

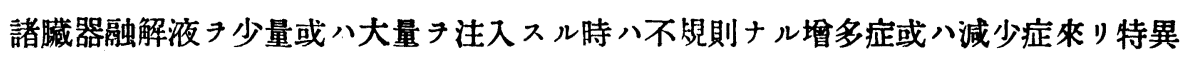
ナル變化キ把握シ難シ。即小量キ注入スルモ骨髓融解液注入，場合，如キ著名ナル白

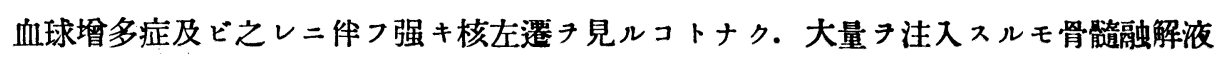
注入二於ヶル如ク決定的ナル隇少症尹招來スルガ如キコトナシ。

\section{第五童 結 論}

(1) 瀉血貧血家鬼二脾藏蒸馏水自家融解液 pro Kilo 0.5gr. 尹非經口的二注入スル

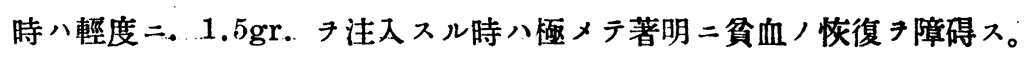

（2）此/場合流血中ノ網狀赤血球八唃血ノ程度二應ジテ常二增加シ骨髓八常二刺戟 狀態二在ルモノニシテ. 赤血球或八骨髓融解液大量注入, 場合/如ク骨髓/造血㙨能 抑制セラレタル結果ニハ非ザルナリ。

( 3 ) 肝㵴蒸餾水自家融解液 pro Kilo 0.5gr. 尹注入スル時八多少貧血八恢復子促進 スルコトアリ。1.5gr. キ連結注入スルモ貧血ノ恢復タ障碍スルコトナシ。網狀赤血 球ニ於テモ認ム可キ變化見ズ。

(4) 肝臟蒸餾水自家融解液 pro Kilo $0.5 \mathrm{gr}$. 洔入ニヨリテ筫血／恢復多少促進七ラ レタルョ以テ直チ二惡性筫血二對スル作用ト同一視ス可カラズ。余ハ之レォ以テ官川 教授ノ唱フルAutohormon，比較的藏器特異性 (Relative specificity) ニョリテ說明 シ得ベシト信ズ。

（5）淋巴腺. 筋肉. 肺藏等, 蒸解水自家融解液キ夫々少量或八大量二注入スルモ筫 血ノ恢復二著シキ影響フ及ボスコトナシ。

(6)白血球像ニ及ボス影䇾八極メテ不規則ニシテ何レモ特異ナリト稱スル校化き認 ムルキ得ズ。

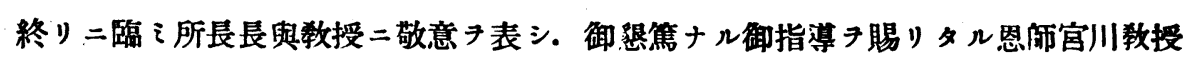
二深甚ナル謝意き表ス。 